Study toward possible sources of polycyclic aromatic hydrocarbons in dried valerian root

M. Strikwold 


\section{Study toward possible sources of polycyclic aromatic hydrocarbons in dried valerian root}




\section{Preface}

The present report describes the results of the study toward possible sources of polycyclic aromatic hydrocarbons in valerian root, which was commissioned by VNK B.V, and carried out in consortium with NPN and Van Hall Larenstein University of Applied Sciences. The research was made possible in part by the KIEM-hbo grant issued by SIA. The author would like to thank the following persons for their contribution to the research described in this report: Leo Bentvelzen, Piet van der Steeg, Han Suelmann and Truus Rigter for their expertise and advise along this research project, Selina Kamps and Tom Wellen for their excellent work on this project during their graduation internship, Roel Nieuwenhuis for chemical analysis, Ricardo Blees, Jan Brouwer, Eeltje Osinga and Karolina Smiech for technical assistance and Peter van der Maas for reviewing this report. 


\section{Summary}

Polycyclic aromatic hydrocarbons (PAHs) are a group of more than hundred compounds that are ubiquitous in our environment. Some of these PAHs are known to be carcinogenic, mutagenic and teratogenic. PAHs have been detected in dried herbs that were cultured in The Netherlands as well as in other European countries above the maximum levels in dried herbs set by the EU (EU, 2015) for benzo(a)pyrene (BaP) and the sum of the following four PAHs BaP, benzo[a]anthracene (BaA), benzo[b]fluoranteen $(\mathrm{BbF})$ and chrysene $(\mathrm{Chr})([\mathrm{PAH} 4)$. The origin of these PAHs in herbs is unknown. VNK cultivates, harvests and dries herbs including valerian and would like to identify the source of PAHs to comply to the EU limits for PAHs in herbs. The goal of the present study was to identify the source of PAHs found in valerian root, and to identify possible measures to reduce the concentration of PAHs in valerian root.

A pot experiment was carried out in which valerian was cultured in a greenhouse for 9 months on blank soil and soil freshly contaminated with low levels of $\mathrm{BaP}, \mathrm{BaA}, \mathrm{BbF}$ and $\mathrm{Chr}$ ranging from 50$1000 \mu \mathrm{g} / \mathrm{kg} \mathrm{dw}$. The accumulation potential of the four PAHs (PAH4) in valerian was assessed and for each PAH4 a linear increase of PAH levels in valerian root was observed with increasing PAH concentrations in soil. The bioconcentrationfactors (BCF) obtained from the freshly spiked soils varied between 0.39 for BaP to 1.9 for $\mathrm{Chr}$, and the BCF for the blank soils containing low background levels of PAH varied between 0.44 for BaP and 1.19 for Chr. In addition, it was observed that the small roots of valerian root contained higher PAH levels than the heart of valerian root.

In conclusion the present study showed that soils that contain PAH4 at low levels can be a likely source of PAHs in valerian root via the uptake of PAH from soil to valerian root. Besides, soil adhering to valerian root and soil and granules encapsulated by valerian root also contribute to PAH levels in valerian root. Reduction measures of PAH in valerian root can best focus on the reduction of soil particles adhering to root surfaces, lowering the PAH concentration in soil (water), and decreasing the bioavailability of PAH from soil. It is, however, advised to first perform a field study toward the uptake of PAH from soil to valerian root to investigate to what extent the results obtained in the pot experiment resemble field conditions. 


\section{Content}

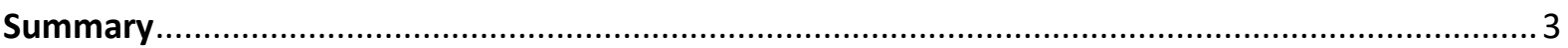

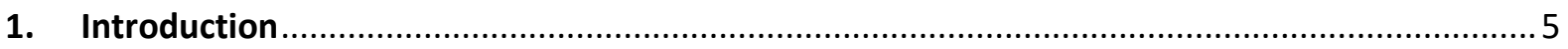

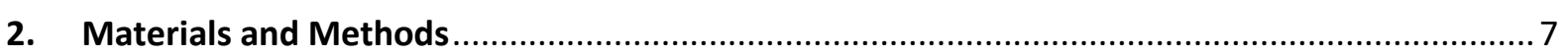

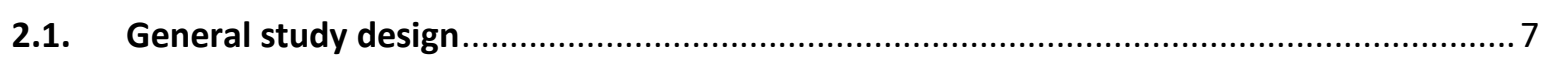

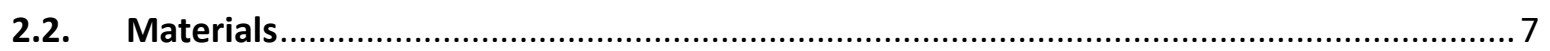

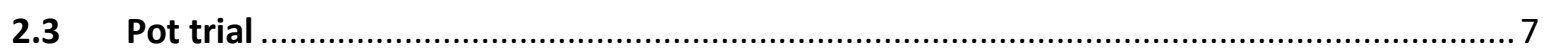

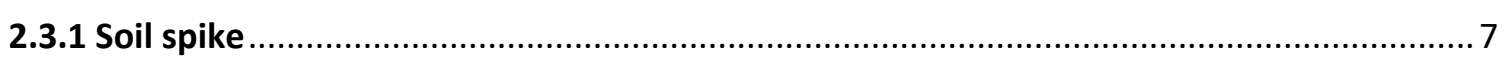

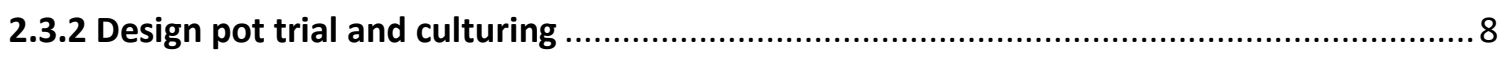

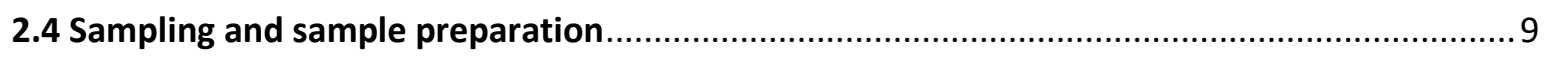

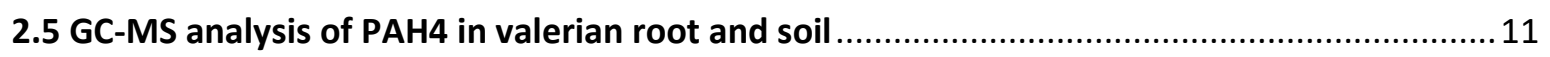

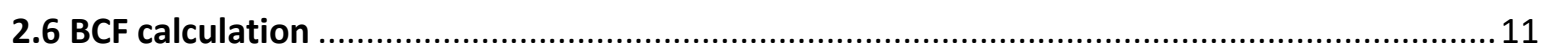

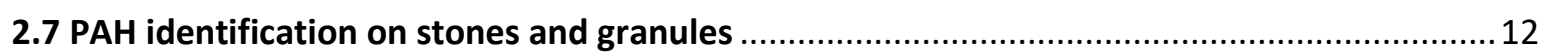

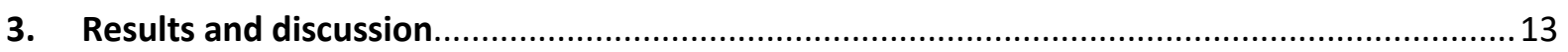

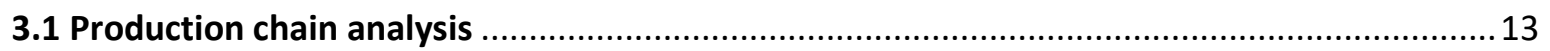

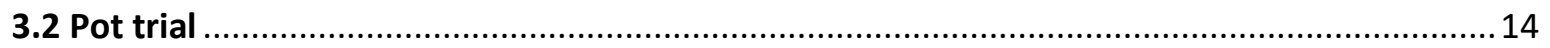

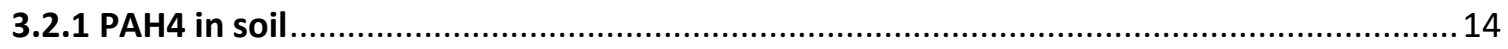

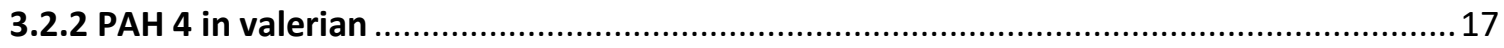

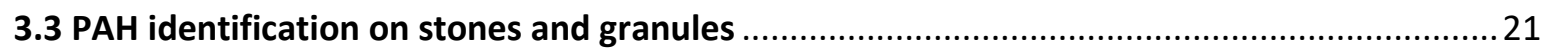

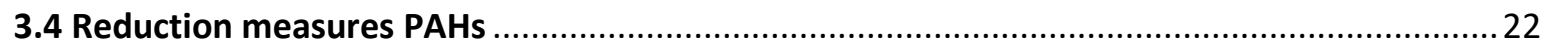

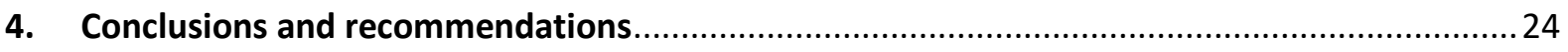

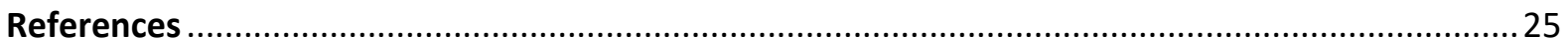

Appendix 1 GC-MS Chromatograms of PAHs in soil and valerian root .........................................29

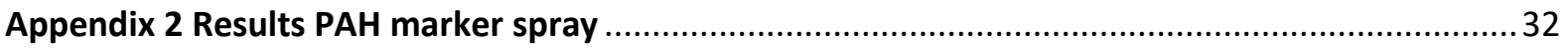




\section{Introduction}

In Europe there are various companies that are active in the cultivation, harvesting, processing and trading of herbs (including valerian, parsley, basil) for food consumption and / or medicinal applications. From 2015 there are European standards for the presence of polycyclic aromatic hydrocarbons (PAHs) in dried herbs. There are various herbs from Europe, including herbs grown in the Netherlands, in which PAHs were found above the maximum levels of PAHs in dried herbs set by the EU (EU, 2015). There are more than 100 types of PAHs. The PAHs that are regulated for dried herbs are benzo[a]pyrene $(\mathrm{BaP})$, benzo[a]anthracene $(\mathrm{BaA})$, benzo[b]fluoranteen $(\mathrm{BbF})$ and chrysene (Chr) and belong to the so-called PAH4. The molecular structure and some physical-chemical properties of the $\mathrm{PAH} 4$ are included in Figure 1.

PAHs are formed during incomplete combustion of organic materials such as oil, coal, gasoline, wood, tobacco and food. The main PAH emissions are from anthropogenic influences. Traffic and industry contribute to this (Abdel-Shaffy and Mansour, 2016). PAHs present in the atmosphere, for example from incomplete combustion processes, can be deposited in other environmental compartments such as water and soil. PAHs can end up in the herbs during cultivation, possibly also during harvesting and transport, during drying and further processing toward a final end product. Some of these PAHs are known to be carcinogenic, mutagenic and teratogenic (Gearhart-Serna et al., 2018). The agricultural sector wants to comply to the EU regulations for PAHs in dried herbs.

VNK cultivates, harvests and dries herbs including valerian. A study conducted by VNK has shown that the presence of PAHs is unlikely to be caused by the indirect drying process that the herbs undergo at VNK, leaving the question what the origin is of these PAHs in the dried herbs. Moreover, a trial research toward PAH concentration in dried herbs, commissioned by NPN, showed that different analytical-chemical laboratories reported different PAH levels for the same herb sample. Insight into the origin of PAH in herbs and the application of an unambiguous analytical method to quantify PAHs in herbs, is important because companies that trade in herbs that exceed the EU limits do not comply with legislation, which can influence the sales potential of the products, the competitive position of the company and possibly entails health risks. Insight into the source of the PAH pollution may provide guidance to take adequate (reduction) measures.

The main research question of the present study was:

What is the source of PAHs found in valerian root, and what are possible measures to reduce the concentration of PAHs in valerian root? 
The present report describes the main findings of the study. Details of the study are included in the bachelor theses of Wellen (2018) and Kamps (2019).<smiles>c1ccc2c(c1)ccc1ccccc12</smiles>

Chrysene

$\mathrm{Mw}=228.29 \mathrm{~g} / \mathrm{mol}$ Boiling point $=437.60^{\circ} \mathrm{C}$ $\log P=5.80$<smiles>c1ccc2cc3c(ccc4ccccc43)cc2c1</smiles>

Benzo[a]anthracene $\mathrm{Mw}=228.29 \mathrm{~g} / \mathrm{mol}$ Boiling point $=448.00^{\circ} \mathrm{C}$ $\log P=5.70$<smiles>C1=Cc2cccc3c2C2C(=Cc4ccccc4C2C=C3)C1</smiles>

Benzo[a]pyrene

$M w=252.29 \mathrm{~g} / \mathrm{mol}$ Boiling point $=495.00^{\circ} \mathrm{C}$ $\log P=6.10$

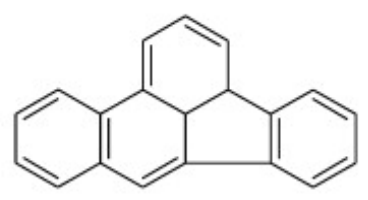

Benzo[b]fluoranthene $M w=252.32 \mathrm{~g} / \mathrm{mol}$ Boiling point $=481.00^{\circ} \mathrm{C}$ $\log P=6.40$

Figure 1 Molecular structure and some physical-chemical properties of the PAH4. (Dos Reis et al., 2013; PubChem, 2018). 


\section{Materials and Methods}

\subsection{General study design}

At first, a production chain analysis at VNK was performed to identify possible sources of PAH4 within the valerian supply chain. To this purpose, a list of possible sources of PAH4 in valerian roots was drawn up by inspecting the whole production chain of valerian root at VNK B.V. for possible sources of PAHs during each step in the production chain, performing exposure calculations of valerian roots to PAHs for the most likely sources, and performing a literature search as reported in more detail by Wellen (2018). Secondly, a pot trial, to study the uptake of PAH4 by valerian root from soil was set-up and carried out, which is described in more detail below. For this purpose a GCMS method for identification and quantification of PAH4 in valerian root and soil was developed, and partially validated as described in more detail by Kamps (2019). Finally, possible reduction measures for PAH in valerian were selected from the literature.

\subsection{Materials}

Acetone (>99\%), magnesium sulphate $\left(\mathrm{MgSO}_{4}\right)$ (>99\%) sodium chloride $(\mathrm{NaCl})(99.5-10.5 \%)$ and acetonitrile (LC-MS grade) were purchased from VWR (The Netherlands), benz[a]anthracene (BaA), benzo[a]pyrene (BaP) (analytical standard), benzo[b]fluoranthene (BbF) (Supelco, analytical standard), chrysene (Chr) (analytical standard) and perylene- $d_{12}$ (per-d12) were obtained from Sigma-Aldrich (The Netherlands) and sodiumacetaat (NaOAC) (99.5\%) was obtained form Chem-Lab

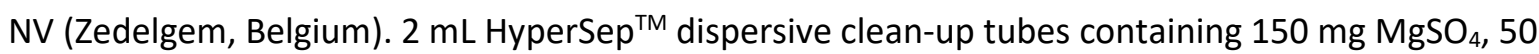
mg PSA and 50 mg C18 were obtained from Thermo scientific (The Netherlands).

\subsection{Pot trial}

\subsubsection{Soil spike}

With permission of the land owner, top soil $(0-20 \mathrm{~cm})$ was collected from an agricultural land side (GPS coordinate $52^{\circ} 50^{\prime} 15.0^{\prime \prime} \mathrm{N}^{\circ} 2^{\prime} 21.0^{\prime \prime} \mathrm{E}$ ) in the province of Drenthe in The Netherlands where valerian was cultured. All soil taken from the field was homogenized in a concrete mixer for $90 \mathrm{~min}$ (blank soil). The homogenised soil was also used as blank soil in the pot experiment. The dry weight percentage was determined by drying $100 \mathrm{ml}$ of soil overnight at $105^{\circ} \mathrm{C}$, and weighing both before and after drying. A part of the blank soil was spiked with $\mathrm{BaA}, \mathrm{BaP}, \mathrm{BbF}$ and Chr to final contamination levels of 50,150 , 450 and $1000 \mu \mathrm{g} / \mathrm{kg} \mathrm{dw}$ soil (background levels of PAHs present in the soils are not reflected in these values). Within a contamination level the spiked concentration of each individual PAH was similar to 
each other. The background concentration of PAH4 was unknown at the time of spiking. First, for each contamination level a stock soil with PAH4 was prepared in a stainless steel pot by adding $400 \mathrm{ml}$ acetone containing PAH4, to $4 \mathrm{~kg}$ fw soil. To mix properly, soil and acetone was added alternately in a stainless steel bucket under constant mixing using a paint mixer powered by a drill. When all of the soil and acetone was mixed, the mixture was homogenised for an additional $2 \mathrm{~min}$. The acetone was evaporated by leaving the pot overnight in a fume hood. Each stock soil was subsequently diluted ten times with homogenised blank soil. To get an as homogeneous soil as possible all the prepared stock soil was used and mixed with blank soil using a concrete mixer for $90 \mathrm{~min}$. The order of mixing was always from a low to a high concentration level to prevent contamination from high to low contamination levels.

\subsubsection{Design pot trial and culturing}

The accumulation of PAH4 from soil to valerian root was studied at five contamination levels being an unspiked soil (blank), 50, 150, 450 and $1000 \mu$ g PAH4/kg dw soil. 10 I plastic pots $(\varnothing 25 \mathrm{~cm}, 20 \mathrm{~cm}$ deep) were filled with $7.5 \mathrm{~kg}$ fw soil. For each contamination level, 5 replicates were used resulting in a total of 25 pots. The pots were placed in rows of five pots, in a randomly assigned position using an online random sequence generator (https://www.random.org/sequences).

Young valerian similar sized seedlings with an average weight of $19.6 \mathrm{~g}(\mathrm{SD} \pm 1.9)$ were planted at the end of June and cultured for 36 weeks. During the entire experiment the 25 pots were surrounded with a row of pots with valerian plants of similar size as the valerian used in the experiment, to ensure each experimental pot was similarly affected by the presence of a neighbor plant.

The pots with valerian were cultured in a greenhouse under natural sunlight or under two $600 \mathrm{~W}$ sodium lamps when the solar radiation was below $100 \mathrm{~W} / \mathrm{m}^{2}$ between 6 am and $10 \mathrm{pm}$. Sunshields closed when the solar radiation was $>400 \mathrm{~W} / \mathrm{m}^{2}$ between 6 am and $8 \mathrm{pm}$. Greenhouse windows opened at a temperature $>18^{\circ} \mathrm{C}$. From the start of the experiment to September 2018 the plants were watered daily with tap water, while from September to the end of the experiment (March 2019) a similar amount of water was given to each pot, with amounts adjusted to the expected water need and ambient temperature. It was ensured that no water leaked from the pots on the dishes that were positioned under each pot separately. The plants were fertilized twice in September and twice in October with DCM liquid fertilizer house \& garden (NPK 6-6-7). 


\subsection{Sampling and sample preparation}

The valerian plant was shaken to remove the bulk of the soil, and the leaves and the stem were removed from the root. The roots were washed in a stainless steel colander with fresh deionized water until the soil was removed. The valerian root and the valerian heart (root core) (see Figure 2) were separated. The heart was cut in pieces of approximately $5 \mathrm{~cm}^{3}$ and washed. It appeared that the heart of valerian root sometimes contained soil. Both the cutted valerian root and the heart were washed again with fresh deionized water to remove as much soil as possible. The roots and heart were dried with Kim Wipe paper for approximately 30 minutes and subsequently grinded in a coffee grinder, then put in glass jars and frozen at $-80^{\circ} \mathrm{C}$ for at least 24 hours, subsequently freezedried (Salmerkipp ALPHA 2-4 LSCbasic freeze-dryer) for $24 \mathrm{~h}$, and homogenised again with a coffee grinder. The freeze dried valerian roots were stored in glass headspace vials at $-80^{\circ} \mathrm{C}$ prior to sample preparation and analysis.

To investigate the concentration of PAH4 in the small roots and the heart of the valerian plant, these parts were collected separately for the plants that were cultured at the highest PAH contamination level of $1000 \mu \mathrm{g} / \mathrm{kg} \mathrm{dw}$.

For each pot separately a homogenised soil sample (100 g) was taken from the soil that was shaken off from the roots at the time of harvesting. The soil sample was frozen at $-80{ }^{\circ} \mathrm{C}$ in a glass jar for $24 \mathrm{~h}$, and subsequently freeze-dried (Salmerkipp ALPHA 2-4 LSCbasic freeze-dryer) for 24 hours. The soil was grind and mixed using a mortar and pestle, and sieved with a stainless steel sieve. Soil particles smaller than $2 \mathrm{~mm}$ were collected in a glass jar. The soils were then stored in a glass headspace vials at $-80^{\circ} \mathrm{C}$ prior to sample preparation and analysis. To investigate the homogeneity of the PAH contamination within a pot, four $50 \mathrm{mg}$ soil samples were taken, representing the upper left, upper right, lower left and lower right part of the pot. This procedure was carried out for the 5 pots of the highest PAH contamination level $1000 \mu \mathrm{g} / \mathrm{kg} \mathrm{dw}$. 

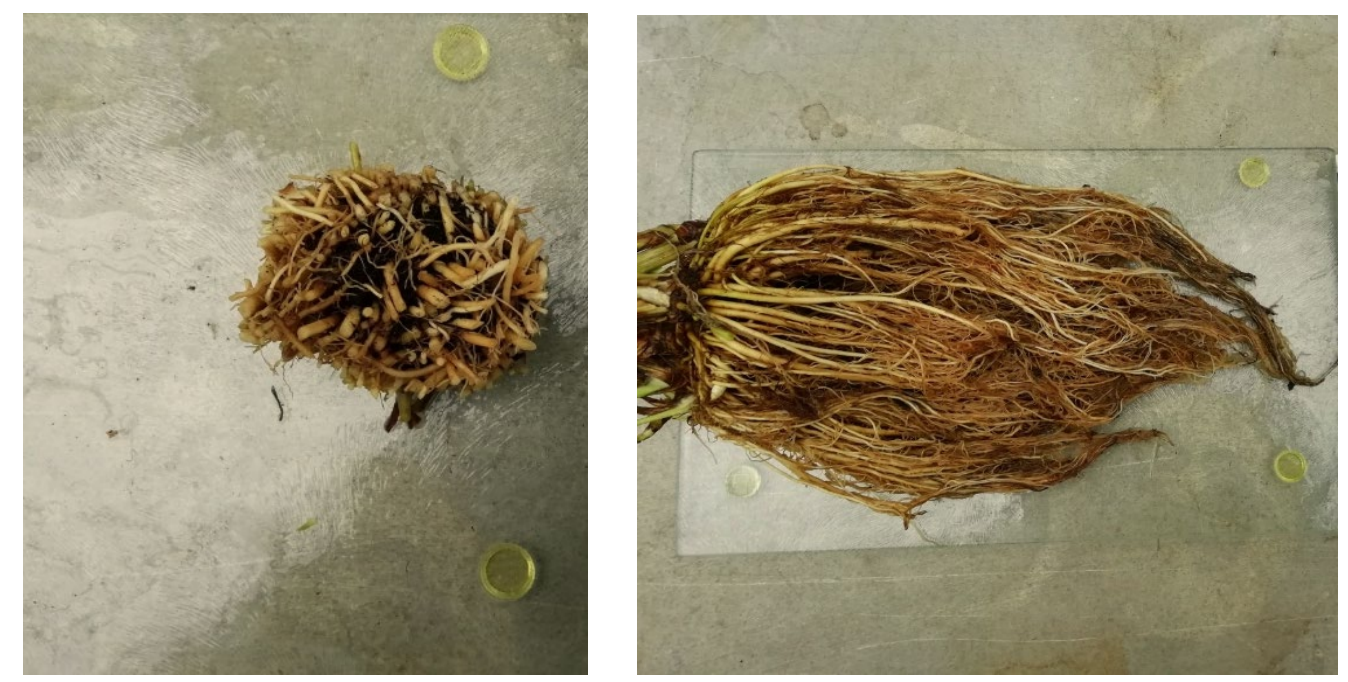

Figure 2 Photo of the heart of the valerian root (left) and the small roots of the valerian root (right) obtained from valerian cultured in pots from September to March 2018.

The QuEChERs method, which has been applied in other studies to extract PAHs from soil and vegetables (Alagić et al., 2016; Cvetkovic et al., 2016; Pule et al., n.d.), was applied with some small modifications to prepare the soil and valerian samples for PAH analysis with GC-MS. For soil, freeze dried soil samples of 5 gram were spiked with the recovery standard per-d-12, (and PAH4 in case of the calibration standards) vortexed for $30 \mathrm{sec}$, and subsequently mixed with $5 \mathrm{ml}$ deionized water and $10 \mathrm{ml}$ acetonitrile in a $50 \mathrm{ml}$ centrifuge tube and shaken for $30 \mathrm{~min} .6 \mathrm{~g} \mathrm{MgSO}_{4}$ and $1.5 \mathrm{~g} \mathrm{NaOAC}$ was added, after 30 seconds vortexing the tubes were shaken on a shaking device for 30 minutes. The samples were subsequently centrifuged at 4,000 g for 5 mnutes, after which $1 \mathrm{ml}$ of the supernatant (acetonitrile layer) was transferred to a clean-up tube containing $150 \mathrm{mg} \mathrm{MgSO}{ }_{4}, 50 \mathrm{mg}$ PSA and $50 \mathrm{mg} \mathrm{C18,} \mathrm{which} \mathrm{was} \mathrm{vortexed} \mathrm{for} 30$ seconds and centrifuged at 10,000 g for $10 \mathrm{~min}$ after which $0.3 \mathrm{ml}$ of the upper layer was transferred to a GC vial.

For valerian, 4 gram of freeze dried valerian were spiked with per-d-12 (and PAH4 in case of the calibration standards) vortexed for $30 \mathrm{sec}$, and subsequently mixed with acetonitrile to a total volume of $8 \mathrm{ml}$ and $7.5 \mathrm{ml}$ MilliQ water in a $50 \mathrm{ml}$ centrifuge tube and shaken for $30 \mathrm{~min} .4 \mathrm{~g} \mathrm{MgSO}_{4}$ and $1 \mathrm{~g} \mathrm{NaCl}$ was added, and the tubes were shaken for $30 \mathrm{~min}$ and subsequently centrifuged at 4,000 $\mathrm{g}$ for 10 minutes. Then $1 \mathrm{ml}$ of the supernatant (acetonitrile layer) was transferred to clean-up tubes containing $150 \mathrm{mg} \mathrm{MgSO}$, $50 \mathrm{mg}$ PSA and $50 \mathrm{mg} \mathrm{C} 18$, which was vortexed for 30 seconds and centrifuged at 10,000 g for $10 \mathrm{~min}$ after which $0.3 \mathrm{ml}$ of the upper layer was transferred to a GC vial. 


\subsection{GC-MS analysis of PAH4 in valerian root and soil}

The PAH analyses were carried out on a GC (Agilent Technologies 6890N) coupled to an Agilent-MS (Agilent Technologies 5973Network MSD) using an Agilent J\&W Select PAH GC column (30 m x 0.25 $\mathrm{mm}, 0.15 \mu \mathrm{m})$. The injection temperature was $300^{\circ} \mathrm{C} .5 \mu \mathrm{L}$ was injected applying a split ratio of 1:1. The initial oven temperature was $70^{\circ} \mathrm{C}$ and was hold for $0.7 \mathrm{~min}$, increased by $85^{\circ} \mathrm{C} / \mathrm{min}$ to $200^{\circ} \mathrm{C}$, increased by $3{ }^{\circ} \mathrm{C} / \mathrm{min}$ to $250^{\circ} \mathrm{C}$ (and hold for $7 \mathrm{~min}$ ), increased by $10^{\circ} \mathrm{C} / \mathrm{min}$ to $280^{\circ} \mathrm{C}$ (and hold for $6 \mathrm{~min}$ ), and increased by $14{ }^{\circ} \mathrm{C} / \mathrm{min}$ to $320^{\circ} \mathrm{C}$ (and hold for $1 \mathrm{~min}$ ). Helium was the carrier gas a constant flow of $2.0 \mathrm{ml} / \mathrm{min}$. Ionisation was carried out in electron impact mode at $70 \mathrm{eV}$. The PAHs were detected in single ion monitoring mode (SIM) at $\mathrm{m} / \mathrm{z} 228.3$ ( $\mathrm{Chr}$ and $\mathrm{BaA}$ ) and 252.3 (BbF and $\mathrm{BaP}$ ) and 264.3 for Per-d12, respectively. The temperatures were for the transfer line $300^{\circ} \mathrm{C}$, for the MS source $300^{\circ} \mathrm{C}$, and for the MS quadrupole $150^{\circ} \mathrm{C}$.

PAH levels were quantified by comparing the peak areas of each individual PAH divided by the peak area of the recovery standard obtained from the soil and valerian samples to matrix matched calibration curves (all $r^{2}>0.997$ ) of each individual PAH corrected for the recovery standard.

Afterwards, PAH4 concentrations in valerian were corrected for soil particles adhering to root surfaces, for which sand levels was determined for each freeze dried valerian root sample. Sand levels were corrected for a 3.3\% organic matter content (reported by the land owner) in the soil that was used for the experiment to represent adhering soil levels. Soil and valerian concentrations that were lower than the lowest standard from the calibration curves were omitted from the analysis.

\subsection{BCF calculation}

Analysis of the soils revealed that PAH4 were already present in blank (unspiked) soils with concentrations ranging from $10.54-118.6 \mu \mathrm{g} / \mathrm{kg} \mathrm{dw}$. The blank soil was considered to be an aged PAH contaminated soil, in which PAHs are considered to be less bioavailable, probably leading to a reduced PAH uptake by roots compared to freshly spiked soils. Therefore, BCFs were calculated for the blank soil, as well as for the freshly spiked soils.

The BCF for the blank soil was defined by the ratio of the PAH concentration in valerian root $(\mu \mathrm{g} / \mathrm{kg} \mathrm{dw})$ and the PAH concentration in soil $(\mu \mathrm{g} / \mathrm{kg} \mathrm{dw})$. The BCF for each PAH4 for the freshly spiked soil was defined by the slope of the first order polynomial function (straight line), describing the relation between the concentration in valerian root $(\mu \mathrm{g} / \mathrm{kg} \mathrm{dw})$ by the concentration in soil $(\mu \mathrm{g} / \mathrm{kg} \mathrm{dw})$. Weighted least squared regression, with weighting by $1 / X^{2}(X=$ concentration in soil) was applied to correct for heteroscedasticity using GraphPad Prism 5.00 (GraphPad, San Diego, CA, USA). 


\subsection{PAH identification on stones and granules}

Stones and granules that were found in soil and in the valerian root from the pot trial were examined for the presence of PAHs with a PAH marker spray (Pak-Marker Spray, Interlab BV, The Netherlands). The granules were sprayed and lit with an UV light. The stones light up at PAH levels $>100 \mathrm{mg} / \mathrm{kg}$. 


\section{Results and discussion}

\subsection{Production chain analysis}

The production chain analyses performed by Wellen (2018) revealed a list of possible sources of PAH pollution in valerian root as depicted in Figure 3. Possible PAH sources that were initially considered in the production chain analysis were background pollution in soil and air, exposure via exhaust fumes during transport, air pollution during heating, pollution during the washing step, PAH uptake via contact materials during processing and transport and exposure via manure and pesticides.

The drying process can be an important source for PAH contamination in herbs when the product comes in direct contact with the heat source (Okenyi, 2016). VNK, however applies an indirect drying process in which a plate exchange heater is used to air dry the valerian roots. Briefly, water is heated to form steam. The steam heats a metal plate, which subsequently heats the air on the other side of the plate which is then used to dry the valerian roots The valerian roots do not have contact with this plate (Wellen, 2018). The air that is used to dry the valerian root is obtained from outside. It was calculated, using a worst-case exposure scenario, that the background concentration of $\mathrm{BaP}$ in air could contribute $2.4 \%$ to the EU standard for $\mathrm{BaP}$ of $10 \mu \mathrm{g} / \mathrm{kg}$ for dried herbs. Worst-case assumptions in the exposure calculation were that $100 \%$ of the $\mathrm{BaP}$ in the air from the drying processes is deposited onto the valerian roots, and that the concentration of BaP in air was $1 \mathrm{ng} / \mathrm{m}^{3}$ air, which is the concentration at the target level for PAHs in air (Smit \& Jansen, 2014), while the reported background concentration in cities varied between 0.2 and $0.4 \mathrm{ng} / \mathrm{m}^{3}$ (Buijsman, 1999). Altogether, this indicated that the drying process is not likely to be a key contributor of PAHs in the valerian root end product.

As outlined by Wellen (2018), the most likely source of PAH in valerian root is the soil. Soil can contribute to PAH in valerian root by two ways, namely soil particles adhering to valerian root surfaces and by the uptake of PAH from soil to root. For two valerian cultivation sites with $\mathrm{PAH} 4$ levels in soil of 334 and $405 \mu \mathrm{g} / \mathrm{kg} \mathrm{dw}$ and $5.9 \%$ and $11.75 \%$ organic matter, adhering soil contributed for $35.5 \%$ and $45.7 \%$ respectively, toward the maximum allowed PAH4 levels in herbs as set by the $E U(E U, 2015)$ when considering the maximum level of $5 \%$ sand in the valerian end product (Wellen, 2018). Alternatively, considering the maximum level of $5 \%$ sand in valerian root and an organic matter content of $10 \%$ in soil, the soil could maximally contain $180 \mu \mathrm{g} / \mathrm{kg} \mathrm{dw}$ of BaP and $900 \mu \mathrm{g} / \mathrm{kg} \mathrm{dw}$ of $\sum \mathrm{PAH} 4$ in order not to exceed the limits for BaP of $10 \mu \mathrm{g} / \mathrm{kg} \mathrm{dw}$ and for $\sum \mathrm{PAH} 4$ of $50 \mu \mathrm{g} / \mathrm{kg} \mathrm{dw}$ respectively, in dried herbs due to adhering soil only. In comparison, the PAH in soil measured in Dutch agricultural sandy soils are $31 \mu \mathrm{g} / \mathrm{kg}$ for BaP and $337 \mu \mathrm{g} / \mathrm{kg}$ for $\sum$ PAH10 (CLO, 
2013) while the background level for $\sum$ PAH10 for Dutch soils is $1500 \mu \mathrm{g} / \mathrm{kg}$ dry matter (Regeling Bodemkwaliteit, 2018).

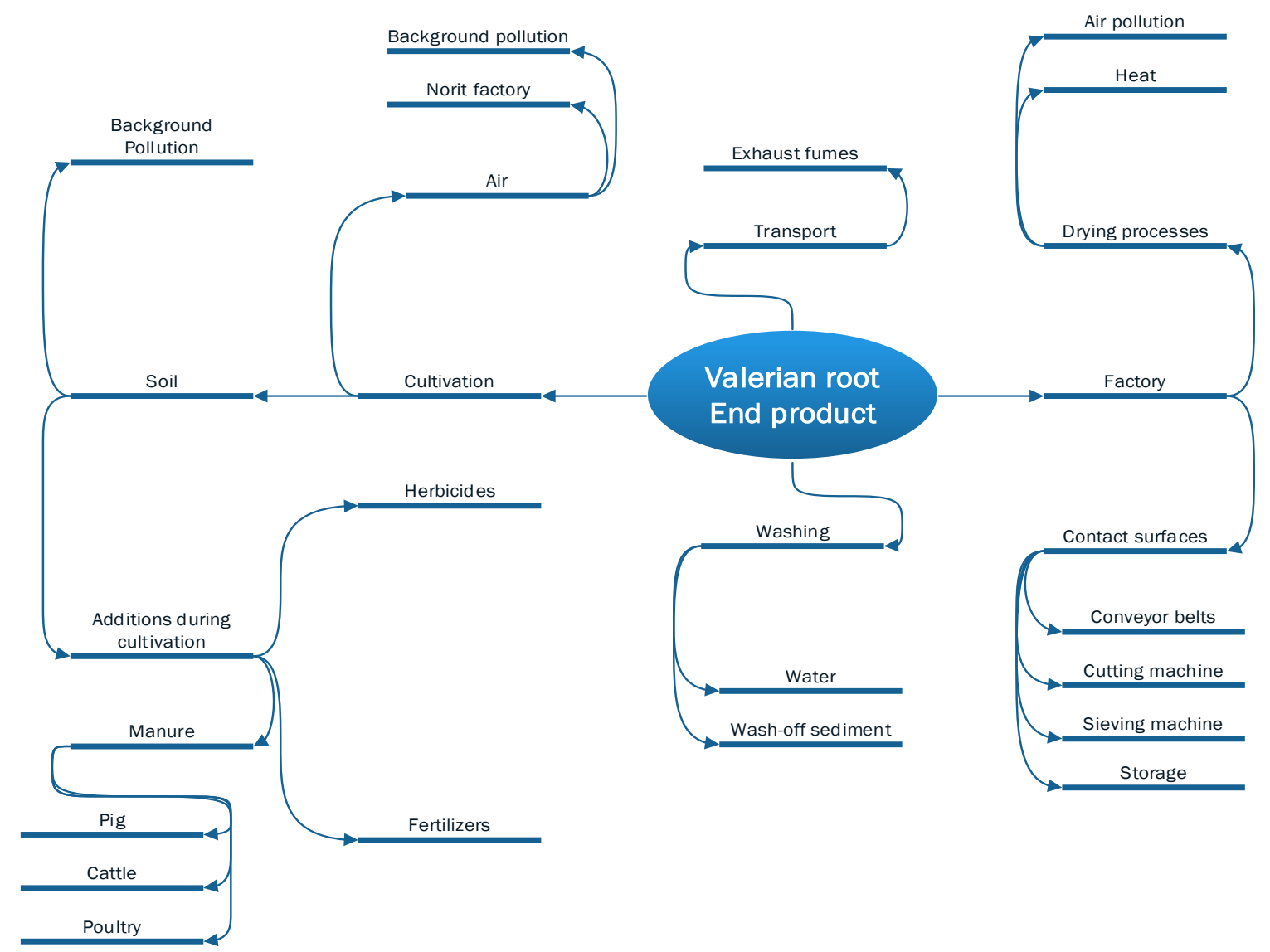

Figure 3 Possible sources of PAHs in the production chain of valerian root at VNK as a result of the production chain analysis using cultivation logs, literature study and visiting the different processes within the production chain (Wellen, 2018).

\subsection{Pot trial}

\subsubsection{PAH4 in soil}

The PAH concentrations in soil (mean of the quintuplicate) at each spike level are reported in Table 1 and presented in Figure 4. Some chromatograms of PAH in soil and valerian are presented in Appendix 1. It appeared that PAH4 was present in the blank soil with mean concentrations varying between 27.6 and $40.8 \mu \mathrm{g} / \mathrm{kg}$ dw for $\mathrm{BaA}$ and $\mathrm{BbF}$, respectively. At each spike level, mean BbF levels were higher compared to the other PAHs. The maximum difference between the average concentrations of the four PAHs within each contamination level was 1.5-fold. 
For each $\mathrm{PAH}$ the ratio of spiked PAH concentration and the measured average PAH concentration in soil increased with increasing spike levels, varying between 1.0-fold for $\mathrm{B}(\mathrm{a}) \mathrm{F}$ at a spike level of 50 $\mu \mathrm{g} / \mathrm{kg} \mathrm{dw}$ to 2.1 -fold for $\mathrm{Chr}$ at a spike level of $1000 \mu \mathrm{g} / \mathrm{kg} \mathrm{dw}$. The difference between the spiked levels and the measured concentration may be due to degradation of $\mathrm{PAH}$ in time due to microbiological activity (Ghosal et al., 2016). Degradation may go faster in freshly spiked soil than aged contaminated soil (Delgado-Balbuena et al., 2013), which may explain why the blank soil contains only little less PAH than the soil at a spike level of $50 \mu \mathrm{g} / \mathrm{kg} \mathrm{dw}$.

The homogeneity of the distribution of the PAH4 in the pots was studied at the contamination level of $1000 \mu \mathrm{g} / \mathrm{kg} \mathrm{dw}$. The maximum coefficient of variation (CV) of the individual PAH4 concentration within the pot with the spike level of $1000 \mu \mathrm{g} / \mathrm{kg} \mathrm{dw}$ was $11.94 \%$ (Chr) and the maximum $\mathrm{CV}$ of the individual PAH4 concentrations between the 5 pots $(n=5)$ was $3.47 \%(\mathrm{BaA})$.

Table 1 Mean $( \pm S D)$ of the individual PAH4 concentrations of the quintuplicate in the blank soil and the freshly spiked soil and the sum of PAH4 concentrations ( $(\mathrm{PAH} 4)$.

\begin{tabular}{|c|c|c|c|c|c|c|}
\hline & \multirow[b]{2}{*}{ Blank } & \multicolumn{5}{|c|}{ Spike concentration $(\mu \mathrm{g} / \mathrm{kg} \mathrm{dw})$} \\
\hline & & $50(n=5)$ & $150(n=5)$ & $450(n=5)$ & $1000(n=5)$ & $1000(n=25)$ \\
\hline $\mathrm{BaA}$ & $\begin{array}{c}27.6 \pm 17.9 \\
(n=5)\end{array}$ & $36.0 \pm 7.29$ & $90.8 \pm 5.25$ & $250 \pm 27.1$ & $494 \pm 17.1$ & $441 \pm 51.1$ \\
\hline Chr & $\begin{array}{c}35.3 \pm 29.9 \\
(n=3)\end{array}$ & $37.8 \pm 14.4$ & $99.6 \pm 16.8$ & $274 \pm 45.7$ & $593 \pm 10.5$ & $522 \pm 62.3$ \\
\hline $\mathrm{BbF}$ & $\begin{array}{c}40.8 \pm 44.4 \\
(n=5)\end{array}$ & $49.0 \pm 16.0$ & $126 \pm 10.6$ & $311 \pm 45.1$ & $646 \pm 20.9$ & $643 \pm 45.3$ \\
\hline $\mathrm{BaP}$ & $\begin{array}{c}38.8 \pm 21.3 \\
(n=4)\end{array}$ & $45.1 \pm 4.37$ & $100 \pm 16.1$ & $279 \pm 58.9$ & $622 \pm 17.5$ & $613 \pm 40.9$ \\
\hline ¿PAH4 & 142 & 168 & 417 & 1113 & 2355 & 2218 \\
\hline
\end{tabular}


A
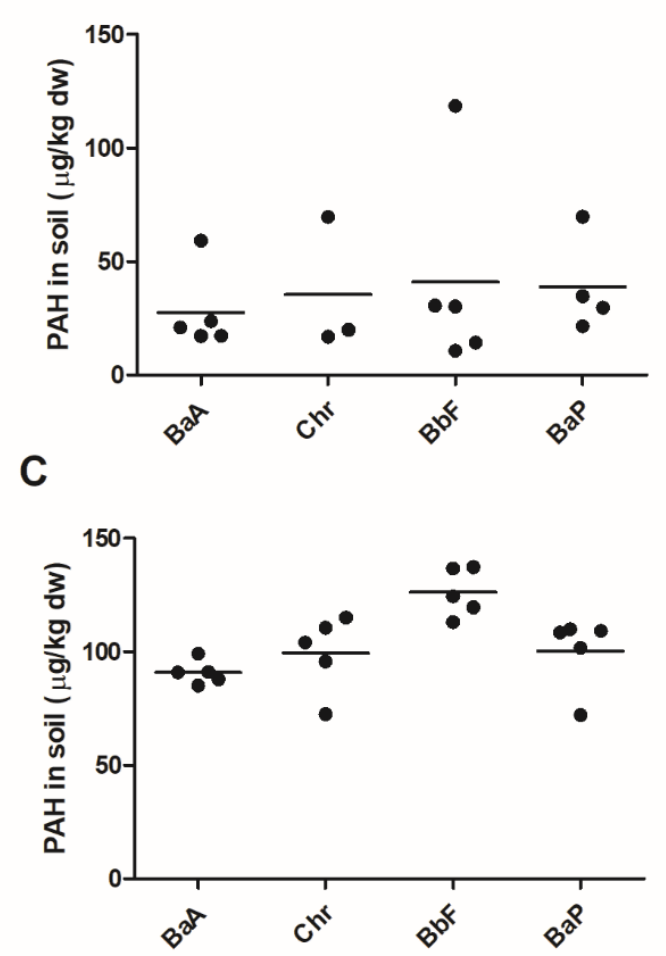

$\mathbf{E}$

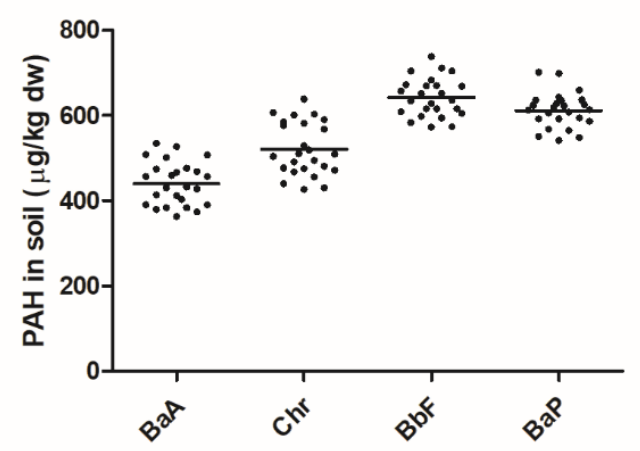

B
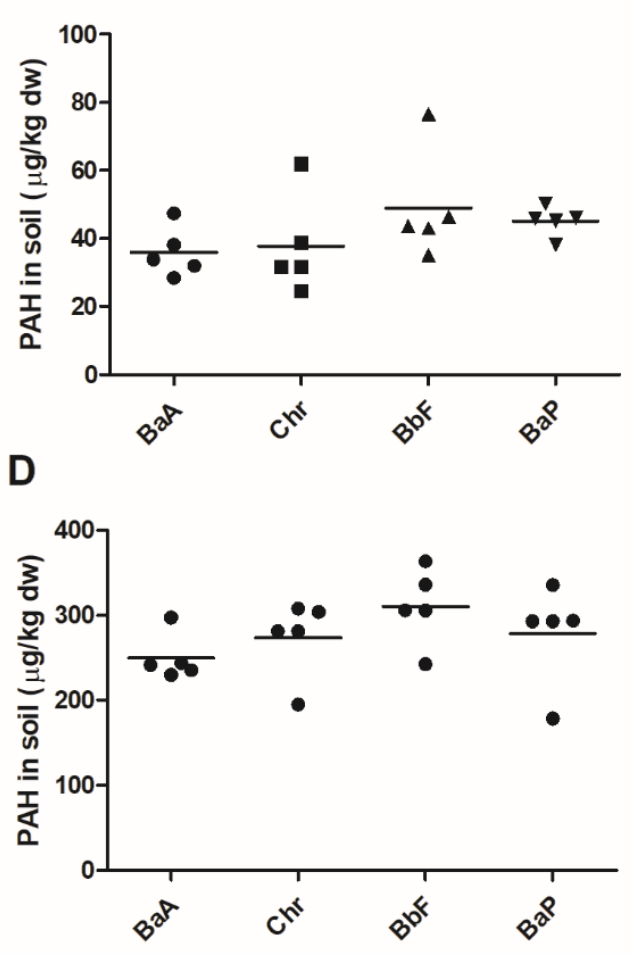

Figure 4 Measured concentration of PAH4 in soil at the blank (background) (A), and at soil contamination levels of 50 (B), 150 (C), 450 (D) and 1000 (E) ( $\mu \mathrm{g} / \mathrm{kg} \mathrm{dw})$. 


\subsubsection{PAH 4 in valerian}

The BCF of the PAHs was assessed via linear regression taking into account the pots spiked with PAH4. In addition, BCF values were based on the ratio of the concentration of PAH in valerian and the concentration of PAH in soil for each spike level separately. The BCF values are included in Table 2 and the regression curves visualizing the bioaccumulation potential are presented in Figure 5. The BCFs that were defined by the slope of the regression curve clearly indicate the uptake of PAH from freshly spiked soils to valerian roots for each $\mathrm{PAH}$, with the highest BCF of 1.9 for Chr followed by its isomer BaA with a BCF of 1.30, and the isomers BbF and BaP with BCFs of 0.77 and 0.39, respectively.

The mean BCF values for $\mathrm{BaA}$, Chr based on the blank experimental pots are lower than the $\mathrm{BCF}$ values based on the pots spiked with $\mathrm{PAH} 4$ and the BCF obtained with linear regression, while the BCF obtained from the blank pots are higher $(\mathrm{BbF})$ than or close to (BaP) the BCFs of the spiked pots obtained by linear regression. The BCF values obtained from the blank pots show a high variability, and therefore these BCF values should be used with caution. The blank pots were assumed to contain aged PAH contaminated soil, in which PAHs due to sequestration may be less bioavailable (Northcott and Jones, 2001; Su and Zhu, 2008) hence reducing the PAH uptake by the valerian roots. The uptake of organic compounds such as PAH is determined by several other factors such the lipid content of the plant tissue (Pullagurala et al. 2018; Lin et al., 2007), the type of plant / crops, and the physical-chemical properties of the PAHs (Fismes et al., 2002). To the best of our knowledge, uptake of PAH from soil by valerian root has not been studied before, but the transfer of $\mathrm{PAH}$ from soil or sludge to other plant and crops has been investigated showing different uptake values. For example, the uptake of PAHs with log Kow values between 5.5 and 6.5, from soil irrigated with waste water to maize resulted in 10log BCFs (based on dry weight) that varied between -1.5 and 0.5 (Zhang et al., 2017). Samsøe-Peterson et al. (2002) reported BCF values (based on dry weight) of $1 \mathrm{E}-3$ to $8 \mathrm{E}-3$ for the uptake of benzo(bjk)fluoranthene and BaP in potato with peel and carrot with peel from a site with very low mean PAH concentrations ranging from 61 and $84 \mu \mathrm{g} / \mathrm{kg}$ $\mathrm{dw}$ (in the study defined as an uncontaminated site), while the BCF values for carrot and squash were even lower. Alagić et al. (2016) reported BCF values for the uptake of PAHs from soil to roots of wild blackberry (Rubus fruticosus L.) of 0.05 for BbF and from 0.24 and 1 for BaP, depending on the sampling sites tested (urban-industrial and rural locations). Because different factors are involved in the transfer of PAHs including the type of plant, extrapolation of the accumulation potential from other plants toward valerian root is difficult. For example, the well branched root system and the lipid content of valerian roots, could explain the relatively higher BCF value for the PAH4 compared to some other plant. 
From the BCF results of the present study, it may be hypothesized that valerian root is able to take up PAHs from aged PAHs contaminated soil at low (background) levels. For example, the mean BaP level in valerian root from the 4 blank experimental pots (1 pot omitted because soil concentration was lower than acceptable detection limit) that contained BaP at soil levels ranging from 21.4-69.7 $\mu \mathrm{g} / \mathrm{kg} \mathrm{dw}$ (mean 38.8, SD \pm 21.3 ), was $11.8 \mu \mathrm{g} / \mathrm{kg} \mathrm{dw}$ (SD \pm 8.3 ), which on average slightly exceed the EU maximum level of $10 \mu \mathrm{g} / \mathrm{kg}$ for B(a)P in dried herbs according (EU 2015). Similarly, the mean $\sum \mathrm{PAH} 4$ concentration of $66.9 \mu \mathrm{g} / \mathrm{kg} \mathrm{dw}$ in valerian roots cultured in the 5 blank pots with average soil concentrations of the 4 individual PAH ranging from to $9.3-25.8 \mu \mathrm{g} / \mathrm{kg} \mathrm{dw}$, exceed the EU standard for $\sum$ PAH4 of $50 \mu \mathrm{g} / \mathrm{kg}$ in dried herbs (EU 2015). The blank soil used in the present study contained PAH levels that correspond to PAH levels found in Dutch agricultural sandy soils (CLO, 2013), but contains less PAH than the background level of $\sum$ PAH10 of $1500 \mu \mathrm{g} / \mathrm{kg}$ dry matter for Dutch soils (Regeling Bodemkwaliteit, 2018).

The EU food legislation refers to good drying practices for dried herbs (EU, 2015). Based on the present findings it may be questioned if the EU standard of $10 \mu \mathrm{g} / \mathrm{kg}$ for dried herbs is reasonable achievable, when valerian is cultured on soils with low PAH levels, i.e. at or lower than background levels which are ubiquitous, even when good drying practices applied. A study of Martena et al. (2011) toward PAH in botanicals reported that relatively high levels of PAH were present in botanicals from Valerian (Valeriana Officinalis L.), and reported that $13 \%$ and $30 \%$ of botanical supplements with Valeriana Officinalis L. as type/ingredient studied between 2008-2009 and 2003-2007 respectively, exceeded the limit of $10 \mu \mathrm{g} / \mathrm{kg} \mathrm{dw}$. The origin, however, could not be related to culturing conditions. Data from the present, together with PAH levels found by suppliers of valerian that apply good drying practice, support the need to study the contribution of PAH uptake from aged low PAH contaminated soils. For a future follow-up study it is recommended measure the PAH transfer at aged low PAH contaminated soils toward valerian root in the field at agricultural sites. The PAH contamination in soil should be measured before initiation the experiment. In addition, it can be valuable to obtain a true blank soil that does not contain the PAHs, and use it to culture valerian to obtain a true blank valerian sample. 
Table 2: Mean $( \pm S D)$ BCF defined by the ratio of the PAH concentration in valerian $(\mu \mathrm{g} / \mathrm{kg} \mathrm{dw})$ and the PAH concentration in soil $(\mu \mathrm{g} / \mathrm{kg} \mathrm{dw})$ obtained from the quintuplicates of the blank soil and the freshly spiked soils, and the BCF obtained by linear regression for freshly spiked soils.

\begin{tabular}{lcccccc}
\hline & & \multicolumn{2}{c}{ BCF ratio } & & BCF slope lin. regression \\
\hline PAH & blank & $50(n=5)$ & $150(n=5)$ & $450(n=5)$ & $1000(n=5)$ & $50-1000(n=20)$ \\
\hline BaA & $0.45 \pm 0.24(n=5)$ & $1.31 \pm 0.52$ & $1.24 \pm 0.24$ & $1.39 \pm 0.51$ & $1.34 \pm 0.33$ & $1.30 \pm$ SE 0.13 \\
$\mathrm{Chr}$ & $1.19 \pm 0.89(n=3)$ & $2.87 \pm 1.28$ & $2.31 \pm 0.35$ & $2.38 \pm 1.01$ & $1.87 \pm 0.49$ & $1.9 \pm$ SE 0.23 \\
$\mathrm{BbF}$ & $1.22 \pm 1.2(n=5)$ & $1.02 \pm 0.24$ & $0.75 \pm 0.12$ & $0.86 \pm 0.38$ & $0.75 \pm 0.20$ & $0.76 \pm$ SE 0.08 \\
$\mathrm{BaP}$ & $0.44 \pm 0.36(n=4)$ & $0.73 \pm 0.55$ & $0.52 \pm 0.14$ & $0.51 \pm 0.24$ & $0.39 \pm 0.12$ & $0.39 \pm$ SE 0.10 \\
\hline
\end{tabular}

A

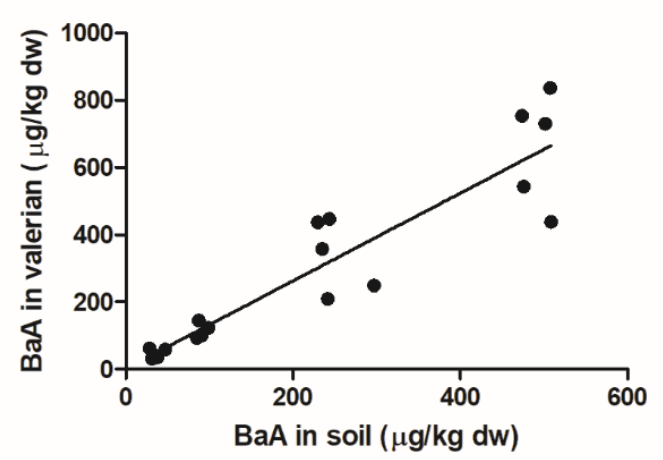

C

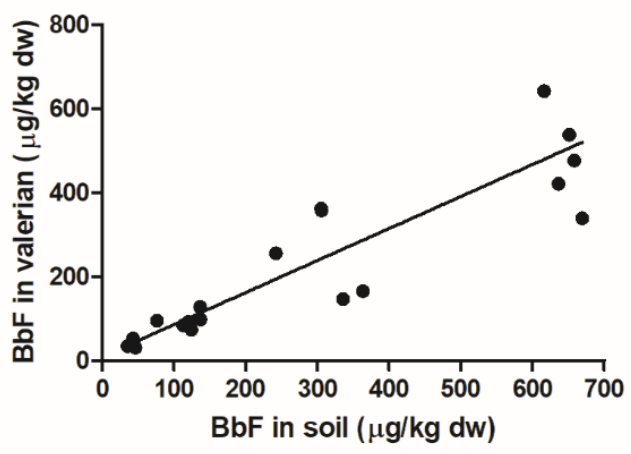

B

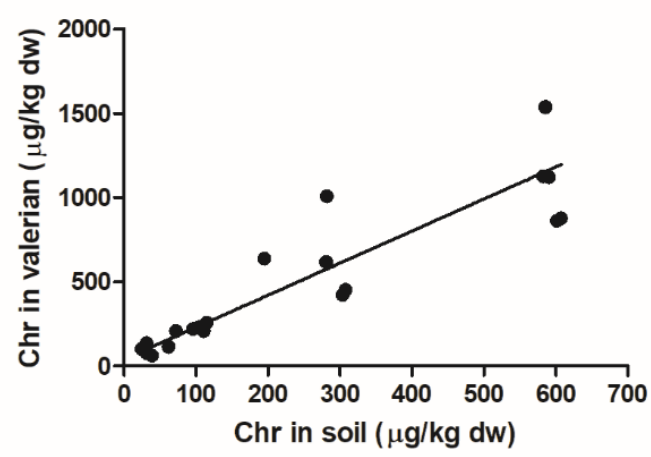

D

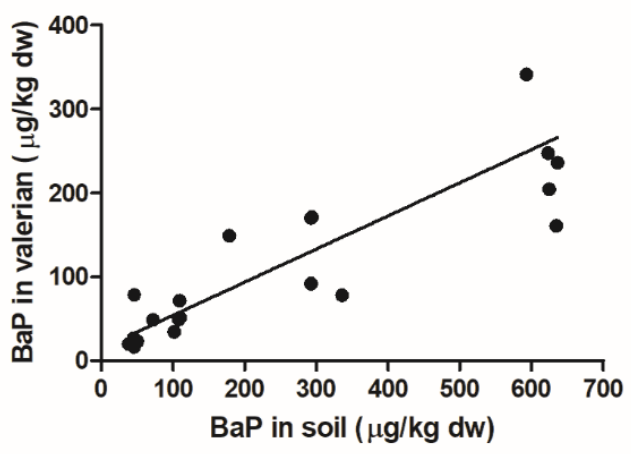

Figure 5 Regression curves visualizing the bioaccumulation potential for $\mathrm{BaA}(\mathrm{A}), \mathrm{Chr}(\mathrm{B}), \mathrm{BbF}(\mathrm{C})$ and $\mathrm{Chr}(D)$. The curves represent the relation between the measured soil concentration $(\mu \mathrm{g} / \mathrm{kg} \mathrm{dw})$ of the pots spiked with PAH4 and measured valerian root concentrations $(\mu \mathrm{g} / \mathrm{kg} \mathrm{dw})$ of the respective pot. 
The distribution of PAH4 in the valerian root taken up from soil spiked to a level of $1000 \mu \mathrm{g} / \mathrm{kg} \mathrm{dw}$ was also studied (see Figure 6), and showed on average a 4.6-fold higher concentration in the small valerian roots compared to the heart of the valerian root. Since the active components of valerian are present at higher concentrations in the small roots (personal communication VNK), a reduction of PAH4 in valerian root products that contain active ingredients cannot be achieved by selecting specific parts of the valerian root for further processing.

A

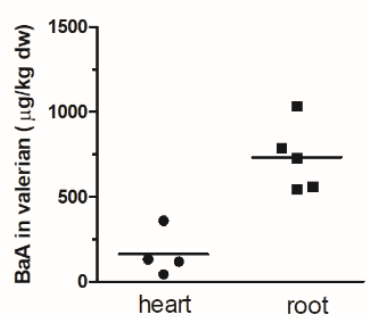

C

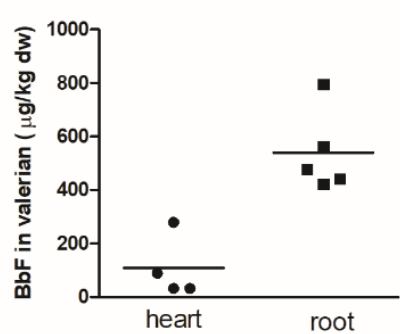

B

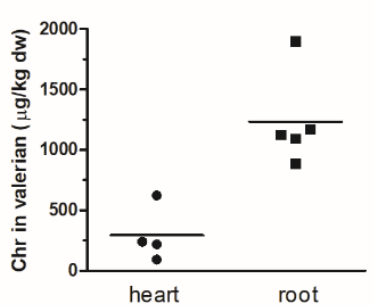

D

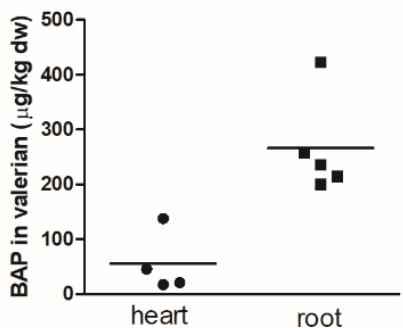

Figure 6 Distribution of PAH concentrations in valerian root distinguishing the heart and the small roots of valerian root. Individual symbols represent valerian root samples obtained from the valerian plant grown in pots $(n=5)$ with soil contamination levels of $1000(\mu \mathrm{g} / \mathrm{kg} \mathrm{dw})$ for $\mathrm{BaA}(\mathrm{A}), \mathrm{Chr}(\mathrm{B}), \mathrm{BbF}$ (C) and $\mathrm{Chr}(\mathrm{D})$. 


\subsection{PAH identification on stones and granules}

Stones and granules were found in many pots, except in pots $1,4,5,8,13,14,15,21$ and 22 . One stone or granule from pot 6 (Picture 1) and pot 25 (see appendix 2 ) tested positive for the presence of PAH (> $100 \mathrm{mg} / \mathrm{kg})$.

A

B
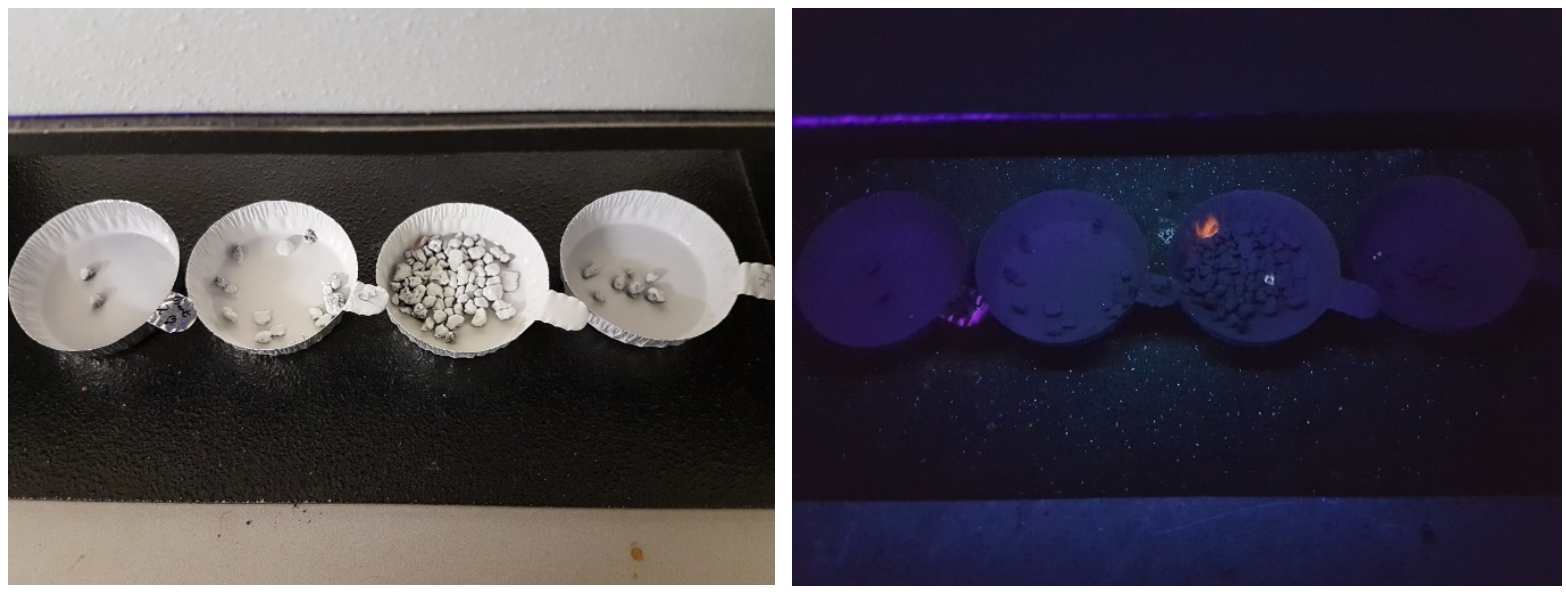

Picture 1 Photo A presents stones sprayed with the PAH marker spray and photo B presents the sprayed stones and granules which are lit up with the UV light. Dishes from left to right contain stones and granules from pot 2 (valerian heart) and pots 3, 6, 7. One stone/granule from pot 6 tested positive for the presence of PAH. The red-lit stone is a pebble. 


\subsection{Reduction measures PAHs}

The amount of PAH in roots of agricultural crops may originate from the uptake of PAHs in the soil solution through root tissues, and originate from soil particles adhering to the root surfaces (Pullagurala et al. 2018), and in the case of valerian also from soil that is encapsulates by valerian root. Other possible routes, which are regarded less relevant for the high molecular weight nonvolatile PAHs used in the present study, are foliar uptake of PAHs which have volatilized from the soil surface, and absorption of PAHs from the atmosphere to leaf surfaces both followed by translocation to roots (Collins et al., 2006; Fismes et al. 2002). To decrease and or eliminate the concentration of $\mathrm{PAH}$ in valerian root, reduction measures should therefor focus on the reduction of soil particles adhering to root surfaces, lowering the PAH concentration in soil (water), and decrease the bioavailability of PAH from soil.

PAH levels may decrease in soil in time via biodegradation. A long term experiment of 25 years with sediments containing PAH levels initially ranging from $30-550 \mathrm{mg} / \mathrm{kg} \mathrm{dw}$, identified a rapid decrease of PAH levels in the first years after applying the contaminated sediment on field, but a very slow decrease at the end of the experiment with degradation of the PAHs ranging from 2-6\% per year (Harmsen and Rietra, 2018). The slow degradation may also be applicable for agricultural soils, such as used in the present study, containing aged low PAH contaminated soils. On a short or mid-long term, the factor time may therefore not substantially reduce PAH toward levels that will not contaminate valerian root. Other physical or chemical remediation activities to reduce the amount of PAH in soil, seem not obvious since the amount of PAH present in soil is already very low (background levels) and also far below the levels that require remediation actions in the context of human or ecotoxicological risks. The background levels for $\sum$ PAH10 in Dutch soil of $1.5 \mathrm{mg} / \mathrm{kg}$ dry matter (Regeling Bodemkwaliteit, 2018) are far below the intervention values of $40 \mathrm{mg} / \mathrm{kg} \mathrm{dw}$ (Staatscourant, 2013) for PAH10 in soil, which requires evaluation of possible adverse health effects for humans and the ecosystem.

Currently, the maximum amount of sand allowed in valerian root by VNK is $5 \%$. A reduction toward a lower percentage may directly affect the amount of PAH. In the production chain of valerian at VNK most of the soil is removed from the valerian root at a washing step of intact valerian roots. A change in the washing step of the valerian roots could possibly result in a decrease of sand present in valerian root, for example by prolongation of the washing step, or a second washing step directly after the first one, or after cutting. Adding a washing step, after cutting the valerian, may potentially influence the drying process. In addition, reducing the amount of soil adhering to valerian root will probably not eliminate PAH from valerian root completely as this will 
not reduce the amount of PAH taken up by the valerian root system which, based on the present findings, seem to contribute more to the presence of $\mathrm{PAH}$ in valerian roots than adhering soil.

Applying surfactants and biosolids may reduce the bioavailability of PAHs as demonstrated by a pot experiment of Lu and Zhu (2009) where the use of the cationic surfactants cetyltrimethylammonium bromide (CTMAB) and dodecylpyridinium bromide (DDPB) resulted in a maximum reduction of phenanthrene and pyrene of $34 \%$ and $53 \%$ in lettuce (Lactuca sativa L.) and of $62 \%$ and $71 \%$ in chrysanthemum (Chrysanthemum coronarium L.), in cabbage (Brassica campestris L.), respectively. Zhan et al. (2015) showed that ammonium reduced the accumulation of the three ring structured PAH phenanthrene from water to lettuce and and whaet, but that nitrate levels increased the accumulation on these crops. It is the question to what extent such measures would be applicable on a large scale and if they are effective at very low PAH concentrations. Moreover, the impact of applying surfactants and additives (on a large scale) on the environmental and the crops, should always be carefully evaluated. Since it seems that PAH4 are already taken up from soil at low PAH values other technical and chemical reduction measures for PAH in soil do not seem a first choice to decrease PAH4 levels in valerian, but this requires further investigation. 


\section{Conclusions and recommendations}

The present project aimed to identify the most likely source of PAHs, which were found in valerian roots that are processed at VNK, and to formulate possible measures to reduce the concentration of PAHs in valerian root. From the present study it appeared that soils that contain PAH4 at low levels, can be a likely source of PAHs in valerian. From the accumulation experiment with freshly spiked soil ranging from $50-1000 \mu \mathrm{g} / \mathrm{kg} \mathrm{dw}$ it can be concluded that PAH4 can be present in valerian root due to uptake of the PAHs from the freshly contaminated soil. In addition, uptake of PAH4 was also observed from blank soil that contained PAHs up to a maximum concentration of $119 \mu \mathrm{g} / \mathrm{kg} \mathrm{dw}$ for $\mathrm{BbF}$. It was found that within valerian root, the small roots contained more PAH4 than the heart of valerian root. The PAH4 may also be present in valerian via soil particles adhering to root surfaces, which at VNK is allowed to be present in the final valerian product at a maximum of $5 \%(\mathrm{~m} / \mathrm{m})$. Besides that, it was observed that valerian root may encapsulate soil as well as PAH containing granules that are present in the soil. Some of these granules may contain very high PAH4 levels exceeding $100 \mathrm{mg} / \mathrm{kg}$, and when not eliminated, give rise to very high inhomogeneous PAH4 levels in valerian root.

Possible reduction measures to decrease the concentration of PAH in valerian root can best focus on reducing the bioavailability of PAH in soil, reducing the amount of soil adhering to valerian roots, and by removing PAH granules from the valerian harvest. It is, however, advised to first perform a field study toward the uptake of PAH from soil to valerian root to investigate to what extent the results obtained from the pot experiment resemble field conditions. In addition the following future research activities are recommended:

- Perform a more extended literature study toward the application of surfactants and biosolids to reduce the bioavailability of PAHs in soils. This literature study should at least address the effectiveness of surfactants and biosolids at representative PAH contaminated soils, costs and possible side effect for soil and crop quality.

- Investigate how and where in the production chain of valerian root PAH granules can be removed most efficiently.

- Investigate possibilities to reduce the amount of soil adhering to valerian root, i.e. by changes in the washing step. 


\section{References}

Abdel-Shaffy H.I., and Mansour M.S.M., 2016. A review on polycyclic aromatic hydrocarbons: Source, environmental impact, effect on human health and remediation. Egypt J Pet 25, 107-123. doi.org/10.1016/j.ejpe.2015.03.011.

Alagić S.Č., Jovanović V.P.S., Mitić V.D., Cvetković J.S., Petrović G.M., Stojanović G.S., 2016. Bioaccumulation of HMW PAHs in the roots of wild blackberry from the Bor region (Serbia): Phytoremediation and biomonitoring aspects. Sci Total Environ. 562 (2016) 561-570.

Buijsman E., 1999. Assessment of air quality for polycyclic aromatic hydrocarbons in the Netherlands. Rapport 729999001, Rijksinstituut voor Volksgezondheid en Milieu (RIVM), Bilthoven.

CLO, 2013. https://www.clo.nl/indicatoren/nl026304-pak-gehalten-in-de-bodem.

Collins C., Fryer M., Grosso A., 2006. Plant Uptake of Non-Ionic Organic Chemicals. Environ. Sci. Technol. 40, 45-52. doi.org/10.1021/es0508166.

Cvetkovic J.S., Mitic V.D., Stankov Jovanovic V.P., Dimitrijevic M.V., Petrovic G.M., Nikolic-Mandic S.D., Stojanovic G.S., 2016. Optimization of the QuEChERS extraction procedure for the determination of polycyclic aromatic hydrocarbons in soil by gas chromatography-mass spectrometry. Anal. Methods 8, 1711-1720. DOI:10.1021/es0508166

Delgado-Balbuena L., Romero-Tepal E.M., Luna-Guido M.L. Marsch R., Dendooven L., 2013. Removal of Anthracene from Recently Contaminated and Aged Soils Water Air Soil Pollut 224, 1420 doi:10.1007/s11270-012-1420-1.

Dos Reis L., Gallart-Mateu D., Pacheco W., Pastor A., de la Guardia M., Cassella R., 2013. Study of passive sampling of polycyclic aromatic hydrocarbons in gas phase using Amberlite XAD resins as filling materials of semipermeable membranes. Microchem Journal 110, 494-500. https://doi.org/10.1016/j.microc.2013.06.003. 
EU, 2015. Commission Regulation (EU) 2015/1933 of 27 October 2015 amending Regulation (EC) No $1881 / 2006$ as regards maximum levels for polycyclic aromatic hydrocarbons in cocoa fibre, banana chips, food supplements, dried herbs and dried spices (Text with EEA relevance). http://data.europa.eu/eli/reg/2015/1933/oj.

Fismes J., Perrin-Ganier C., Empereur-Bissonnet P., Morel J.L., 2002. Soil-to-root transfer and translocation of polycyclic aromatic hydrocarbons by vegetables grown on industrial contaminated soils. J Environ Qual. 31, 1649-56. DOI:10.2134/jeq2002.1649.

Gearhart-Serna L.M., Jayasundara N., Tacam Jr M., Di Giulio R., Devi G.R., 2018. Assessing Cancer Risk Associated with Aquatic Polycyclic Aromatic Hydrocarbon Pollution Reveals Dietary Routes of Exposure and Vulnerable Populations. J Environ Public Health. 2018: 5610462 1-10. doi: $10.1155 / 2018 / 5610462$.

Ghosal D., Ghosh S., Dutta T.K., Ahn Y., 2016. Current State of Knowledge in Microbial Degradation of Polycyclic Aromatic Hydrocarbons (PAHs): A Review. Front. Microbiol. 7:1369. doi:10.3389/fmicb.2016.01369.

Harmsen J., Rietra R.P.J.J., 2018. 25 years monitoring of PAHs and petroleum hydrocarbons biodegradation in soil. Chemosphere 207, 229-238. https://doi.org/10.1016/j.chemosphere.2018.05.043.

Kamps S., 2019. Polycyclic aromatic hydrocarbons in herbs. Development, optimization and validation of a GC-MS method for the analysis of polycyclic aromatic hydrocarbons in valerian root. Bachelor thesis, Van Hall Larenstein University of Applied Sciences, Leeuwarden, The Netherlands.

Lin H., Tao S., Zuo Q., Coveney R., 2007. Uptake of polycyclic aromatic hydrocarbons by maize plants. Environ. Pollut. 148, 614-619. https://doi.org/10.1016/j.envpol.2006.11.026.

Lu L. and Zhu L., 2009. Reducing plant uptake of PAHs by cationic surfactant-enhanced soil retention. Environ Pollut 157, 1794-1799. DOI: 10.1016/j.envpol.2009.01.028. 
Martena M.J., Grutters M.M.P., De Groot H.N., Konings E.J.M., Rietjens I.M.C.M., 2011. Monitoring of polycyclic aromatic hydrocarbons (PAH) in food supplements containing botanicals and other ingredients on the Dutch market. Food Addit Contam Part A, 28, 925-942, DOI:10.1080/19440049.2011.569573.

Northcott G.L., Jones K.C., 2001. Partitioning, extractability and formation of nonextractable PAH residues in soil. I. Compound differences in aging and sequestration. Environ Sci Technol 35, 11031110. DOI:10.1021/es000071y.

Okenyi A.D., Ubani C.S., Oje O.A., Onwurah I.N.E., 2016. Levels of polycyclic aromatic hydrocarbon (PAH) in fresh water fish dried with different drying regimes. J Food Meas Charact 10, 405-410. DOI https://doi.org/10.1007/s11694-016-9319-y.

Pubchem, 2018. www.pubchem.com. Last accessed, June 2018.

Pule B.O., Mmualefe L.C., Torto N. Analysis of Polycyclic Aromatic Hydrocarbons in Soil with Agilent SampliQ QuEChERS AOAC Kit and HPLC-FLD. Application Note. Agilent Technologies, MontluçonCedex, France.

Pullagurala V.L.R., Rawat S., Adisa I.O., Hernandez-Viezcas J.A., Peralta-Videa J.R., Gardea-Torresdey J.L., 2018. Plant uptake and translocation of contaminants of emerging concern in soil. Sci Total Environ 636, 1585-1596. https://doi.org/10.1016/j.micron.2017.01.004

Regeling Bodemkwaliteit. https://wetten.overheid.nl/BWBR0023085/2018-11-30\#BijlageB. Last accessed 12-10-2019.

Samsøe-Petersen L., Larsen E.H., Larsen P.B., Bruun P., 2002. Uptake of Trace Elements and PAHs by Fruit and Vegetables from Contaminated Soils. Environ. Sci. Technol. 2002, 36, 3057-3063. DOI:10.1021/es015691t.

Smit C.E., Jansen M.P.M., 2014. Luchtnormen voor zeer zorgwekkende stoffen. Rijksinstuituut voor volksgezondheid en milieu (RIVM), Bilthoven. 
Staatscourant, 2013. Circulaire Bodemsanering per 1 juli 2013.

https://wetten.overheid.nl/BWBR0033592/2013-07-01

Su Y-H., Zhu Y-G., 2008. Uptake of selected PAHs from contaminated soils by rice seedlings (Oryza sativa) and influence of rhizosphere on PAH. Environ pollut 155, 359-365.

DOI:10.1016/j.envpol.2007.11.008.

Wellen T., 2018. Polycyclic aromatic hydrocarbons in herbs. A study into the possible sources of Polycyclic aromatic hydrocarbons in valerian root. Bachelor thesis, Van Hall Larenstein University of Applied Sciences, Leeuwarden, The Netherlands.

Zhan X., Yuan J., Yue L. Xu G., Hu B., Xu R., 2015. Response of uptake and translocation of phenanthrene to nitrogen form in lettuce and wheat seedlings. Environ Sci Pollut Res 22, 6280-6287. https://doi.org/10.1007/s11356-014-3834-3.

Zhang S., Yao H., Lu Y., Yu X., Wang J., Sun S., Liu M., Li D., Li Y-F., Zhang D., 2017. Uptake and translocation of polycyclic aromatic hydrocarbons (PAHs) and heavy metals by maize from soil irrigated with wastewater. Sci Rep 7, 12165. doi:10.1038/s41598-017-12437-w. 


\section{Appendix 1 GC-MS Chromatograms of PAHs in soil and valerian root}

Figures 1-6 show examples of some chromatograms of the GC-MS measurements of $\mathrm{BaA}, \mathrm{Chr}, \mathrm{BbF}$, $\mathrm{BaP}$ and Per-d12 in soil and valerian root.

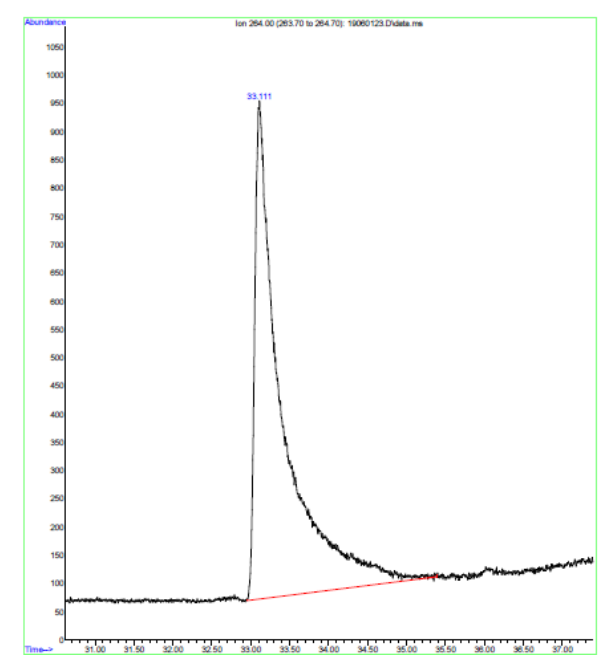

Figure 1 GC-MS chromatogram of per-d1 in blank soil.

A

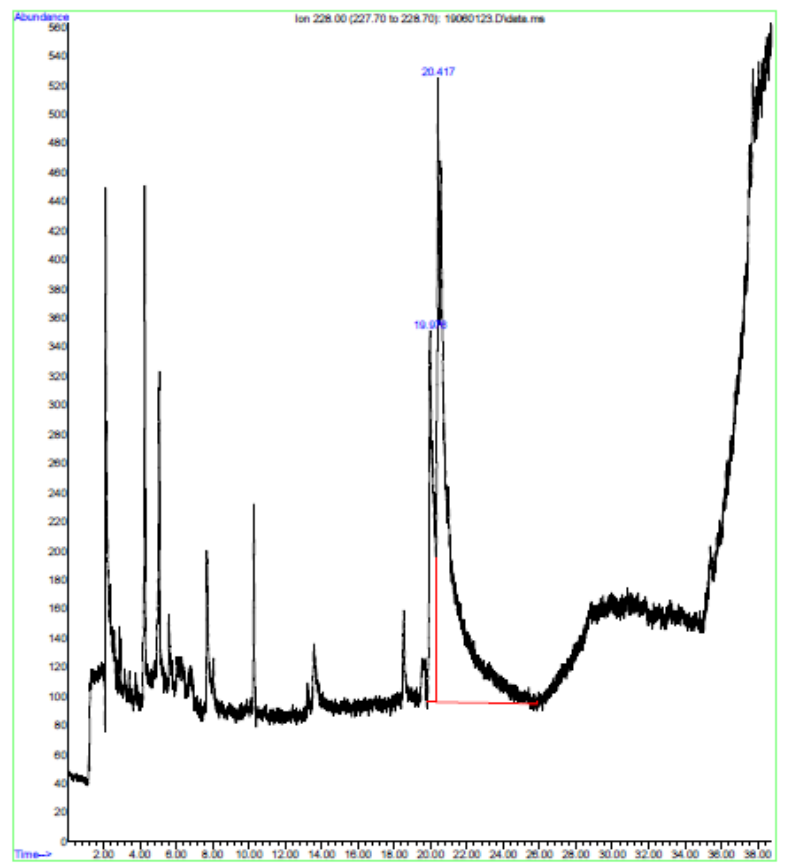

B

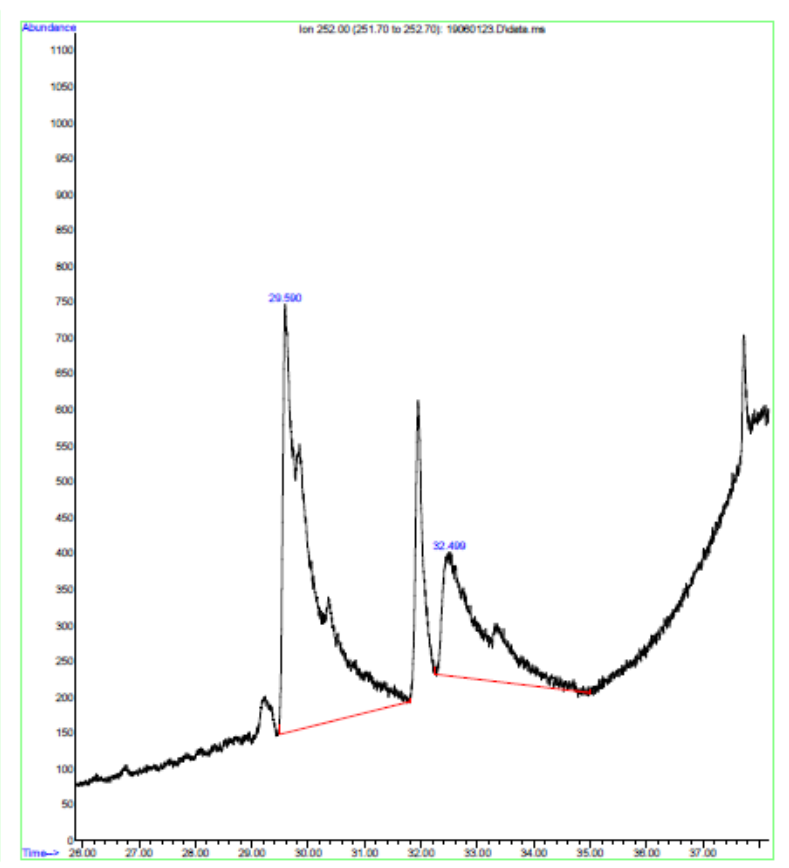

Figure $2 \mathrm{GC}-\mathrm{MS}$ chromatogram of $\mathrm{BaA}$ and $\mathrm{Chr}(\mathrm{A})$ and $\mathrm{BbF}$ and $\mathrm{BaP}(\mathrm{B})$ in valerian root cultured in blank soil. 
A

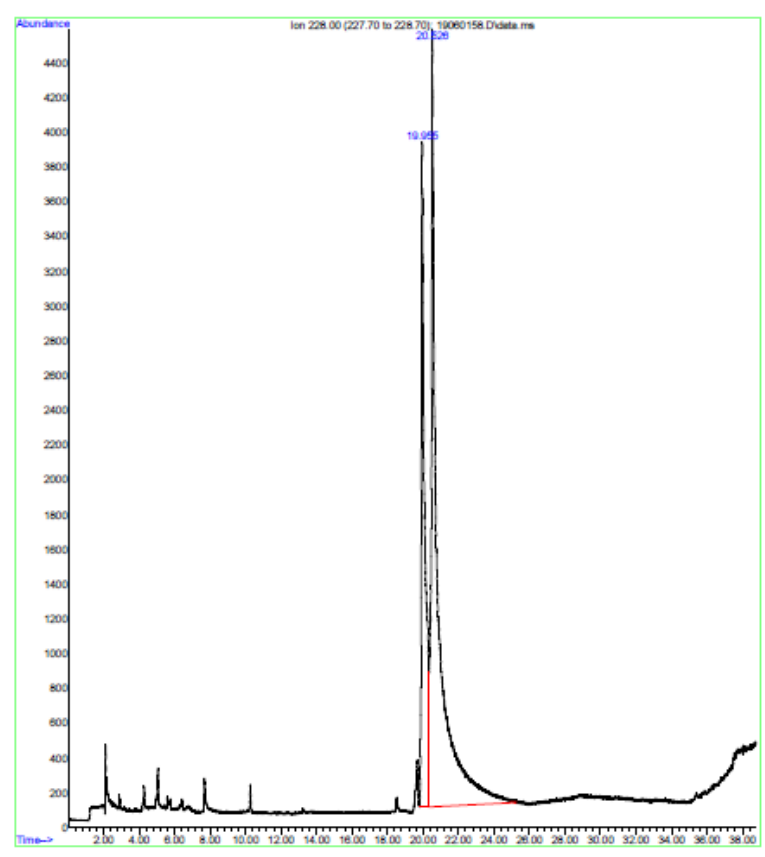

B

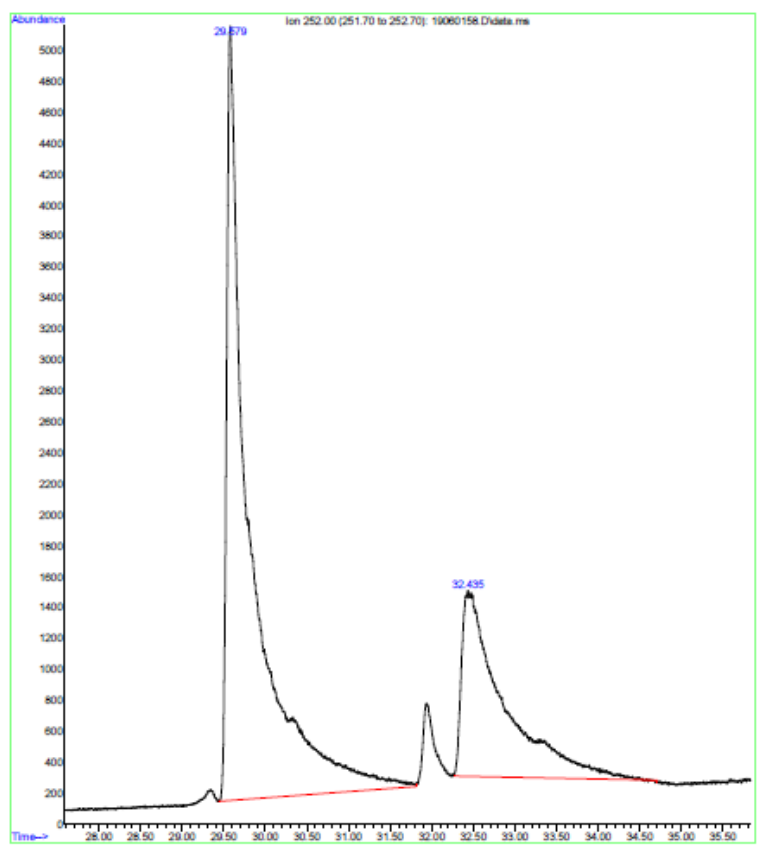

Figure $3 \mathrm{GC}-\mathrm{MS}$ chromatogram of $\mathrm{BaA}$ and $\mathrm{Chr}(\mathrm{A})$ and $\mathrm{BbF}$ and $\mathrm{BaP}(\mathrm{B})$ in soil contaminated with individual PAH4 levels of $1000 \mu \mathrm{g} / \mathrm{kg} \mathrm{dw}$.

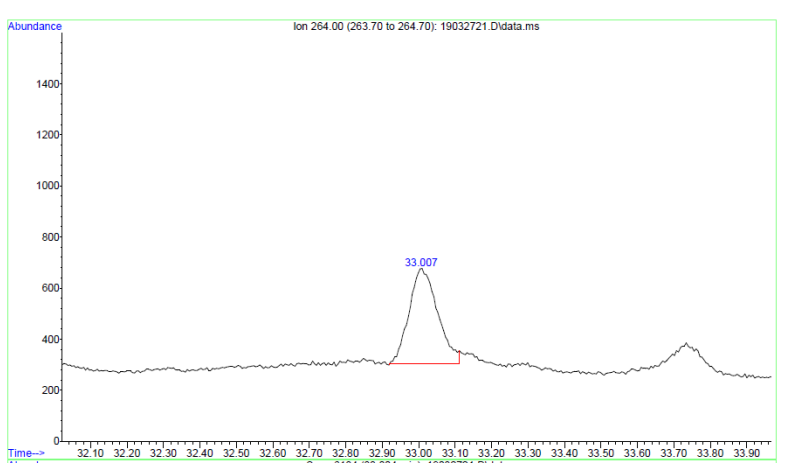

Figure 4 GC-MS chromatogram of per-d1 in valerian root cultured in blank soil. 
A

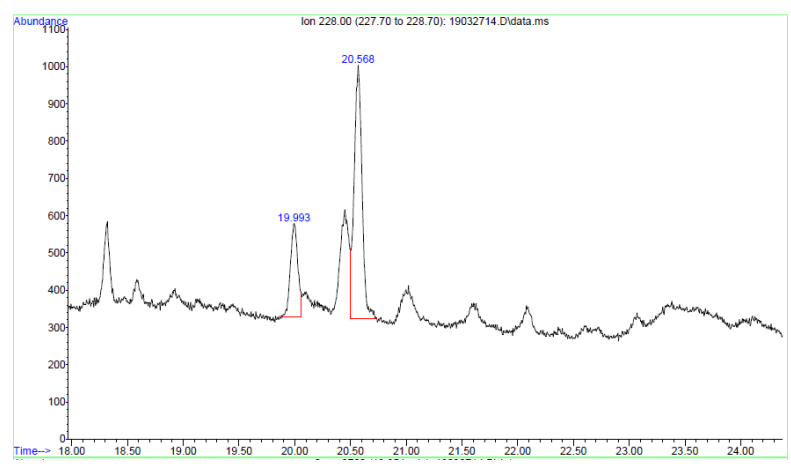

B

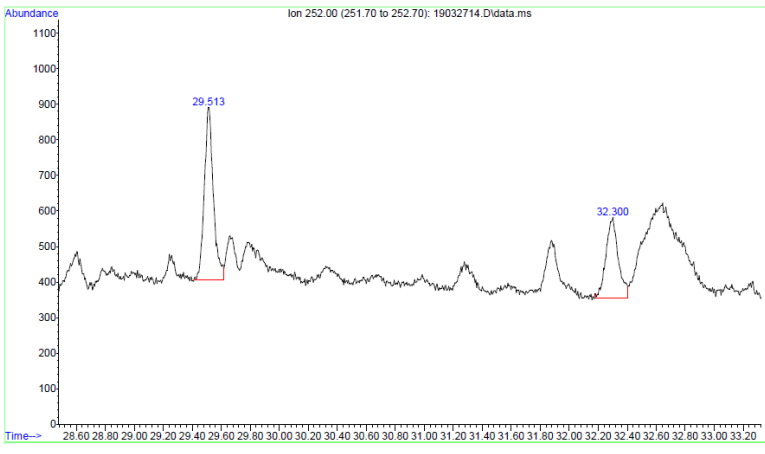

Figure 5 GC-MS chromatogram of $\mathrm{BaA}$ and $\mathrm{Chr}(\mathrm{A})$ and $\mathrm{BbF}$ and $\mathrm{BaP}(\mathrm{B})$ in valerian root cultured in blank soil.

A

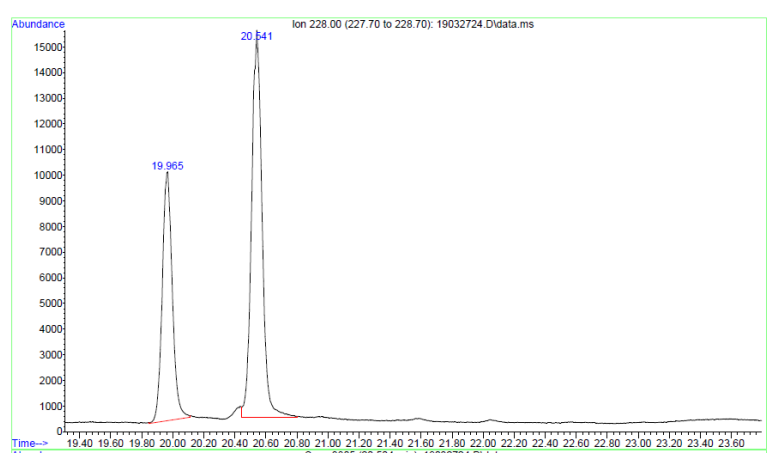

B

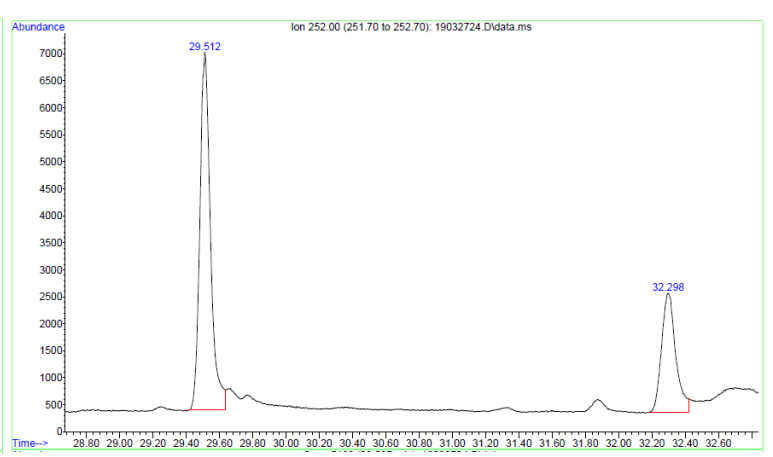

Figure 6 GC-MS chromatogram of $\mathrm{BaA}$ and $\mathrm{Chr}(\mathrm{A})$ and $\mathrm{BbF}$ and $\mathrm{BaP}(\mathrm{B})$ in valerian root cultured in soil contaminated with individual PAH4 levels of $1000 \mu \mathrm{g} / \mathrm{kg} \mathrm{dw}$. 


\section{Appendix 2 Results PAH marker spray}

Results of the PAH marker spray applied on stones and granules from the soil and valerian obtained from the pot experiment are included in the pictures 1-4. Photo's A show stones sprayed with PAH marker spray and photo's B present the sprayed stones and granules which lit up with the UV light.

A

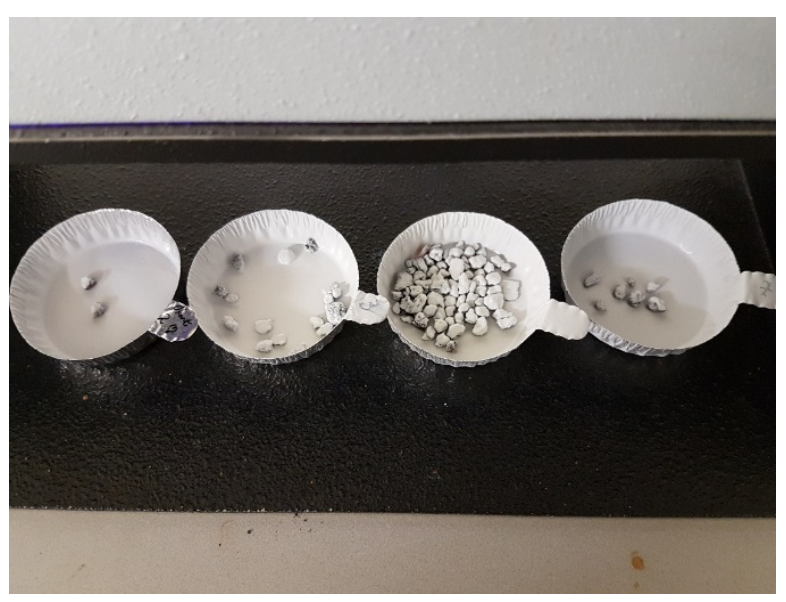

B

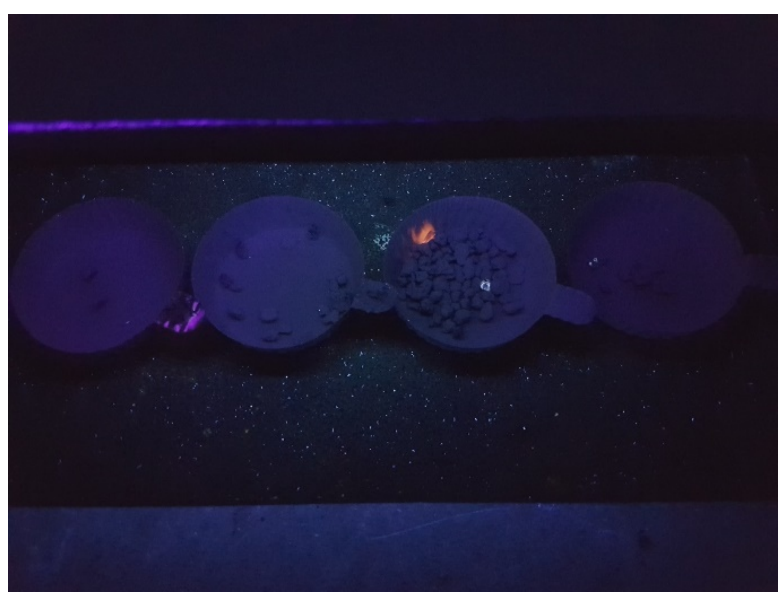

Picture 1 Dishes from left to right contain stones and granules from pot 2 (valerian heart) and pots 3 , 6,7 . One stone/granule from pot 6 tested positive for the presence of PAH. The red-lit stone is a pebble.

A

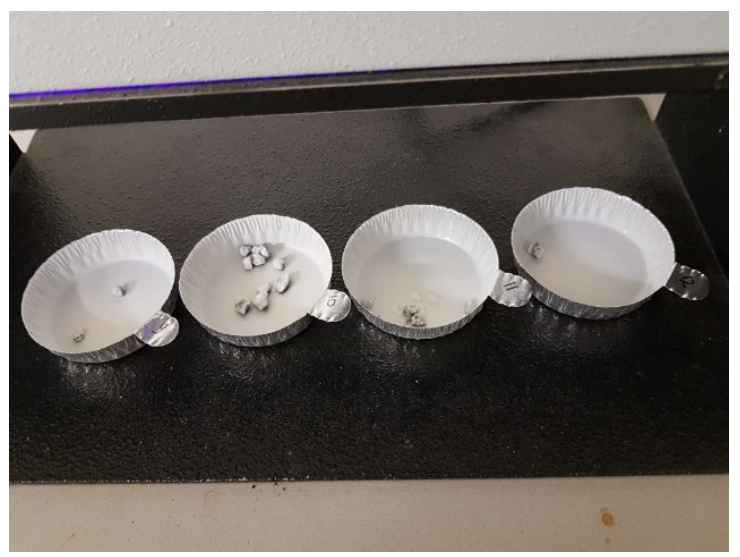

B

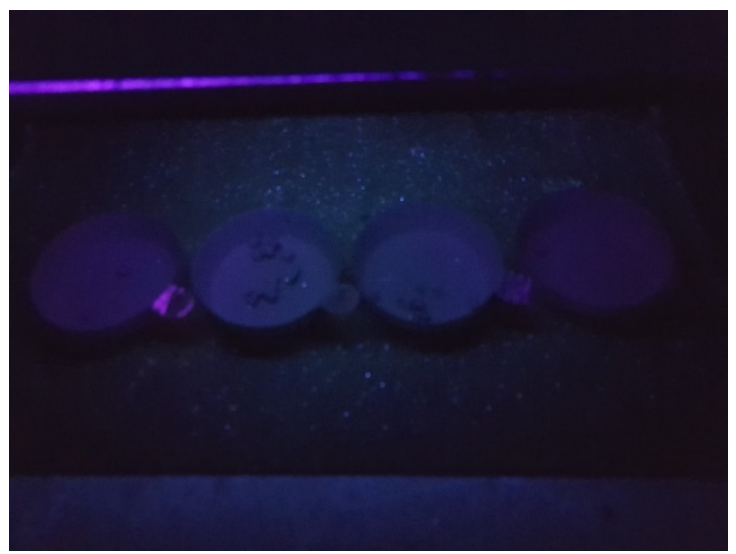

Picture 2 Dishes from left to right contain stones and granules from pots 9, 10, 11, 12 . No stones or granules tested positive for the presence of PAHs. 
A

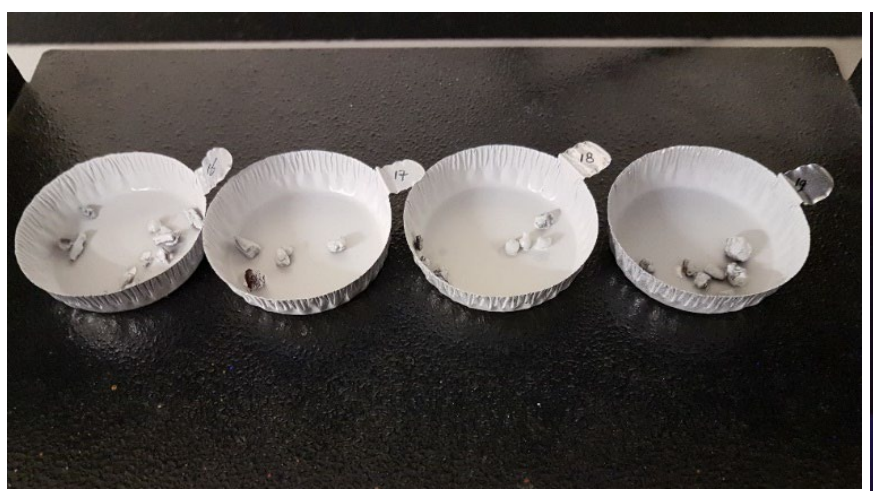

B

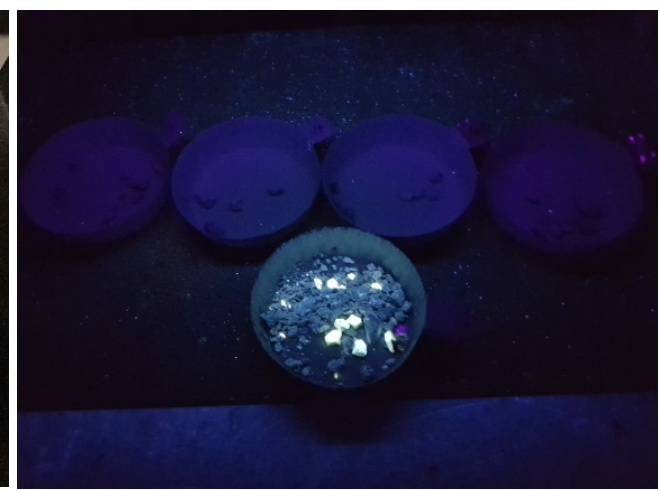

Picture 3 Dishes from left to right contain stones and granules obtained from pots $16,17,18,19$. An extra dish (sample VNK 10-8-18) with some stones that tested positive on the presence of PAH is placed at picture B for comparison. No stones or granules form pots 16, 17, 18 and 29 tested positive for the presence of PAHs.

A

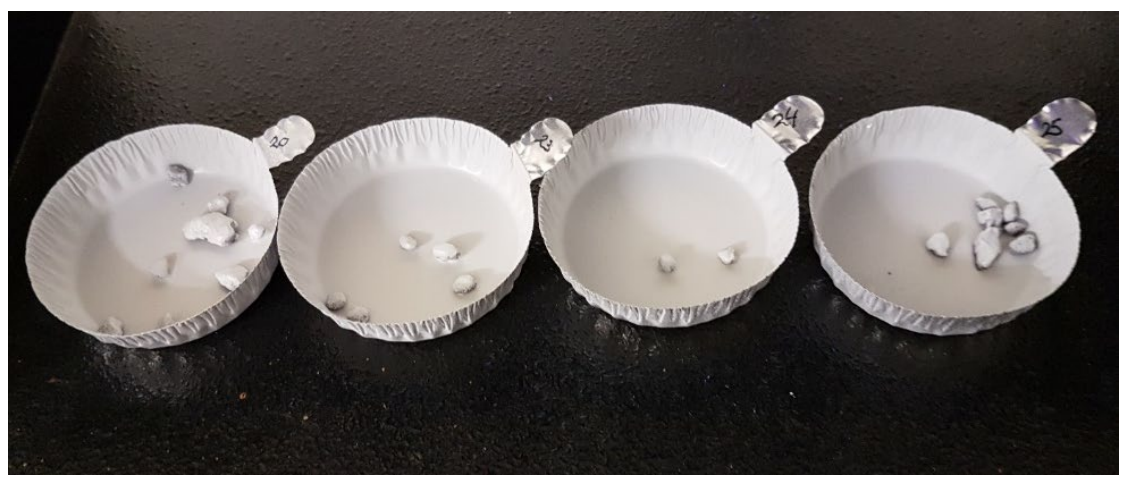

B

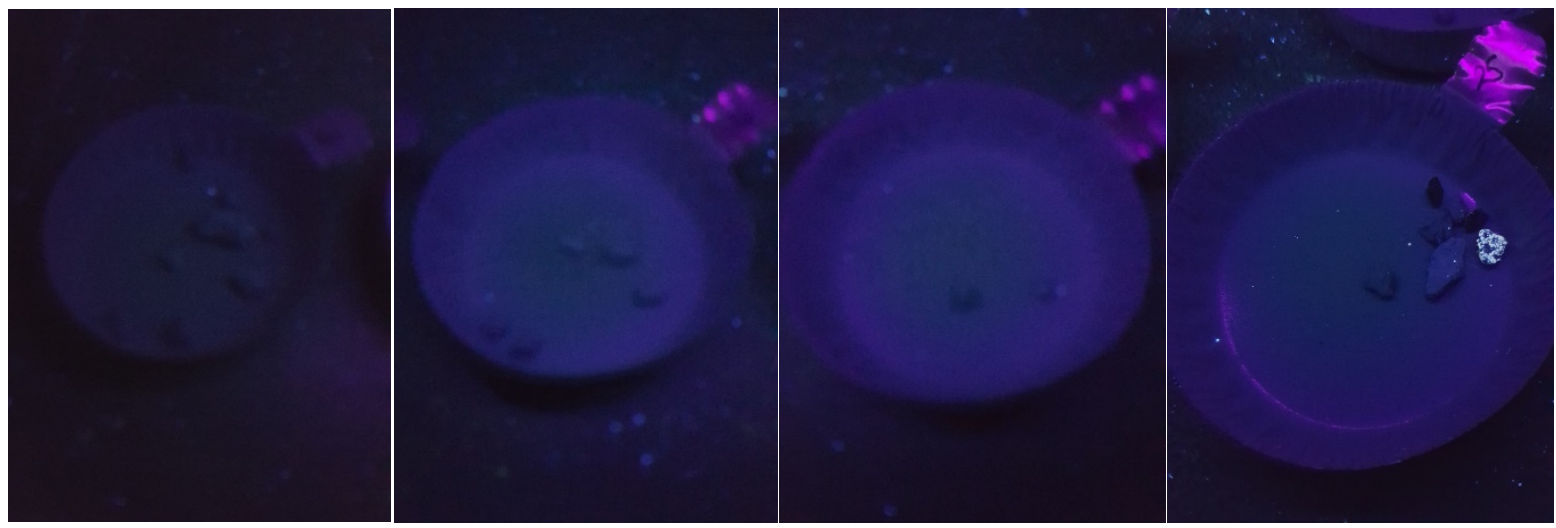

Picture 4 Dishes from left to right contain stones and granules found in pots $20,23,24,25$. One stone from pot 25 tested positive for the presence of PAHs. 